Universidad de Lima

Facultad de Comunicación

Carrera de Comunicación

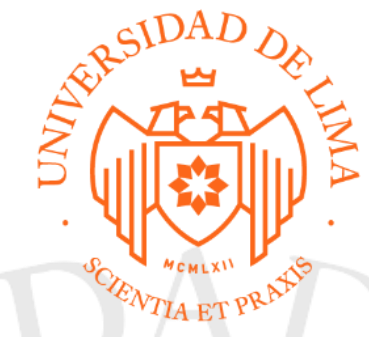

\title{
PROYECTO NUDO
}

Trabajo de Suficiencia Profesional para optar el Título Profesional de Licenciado en Comunicación

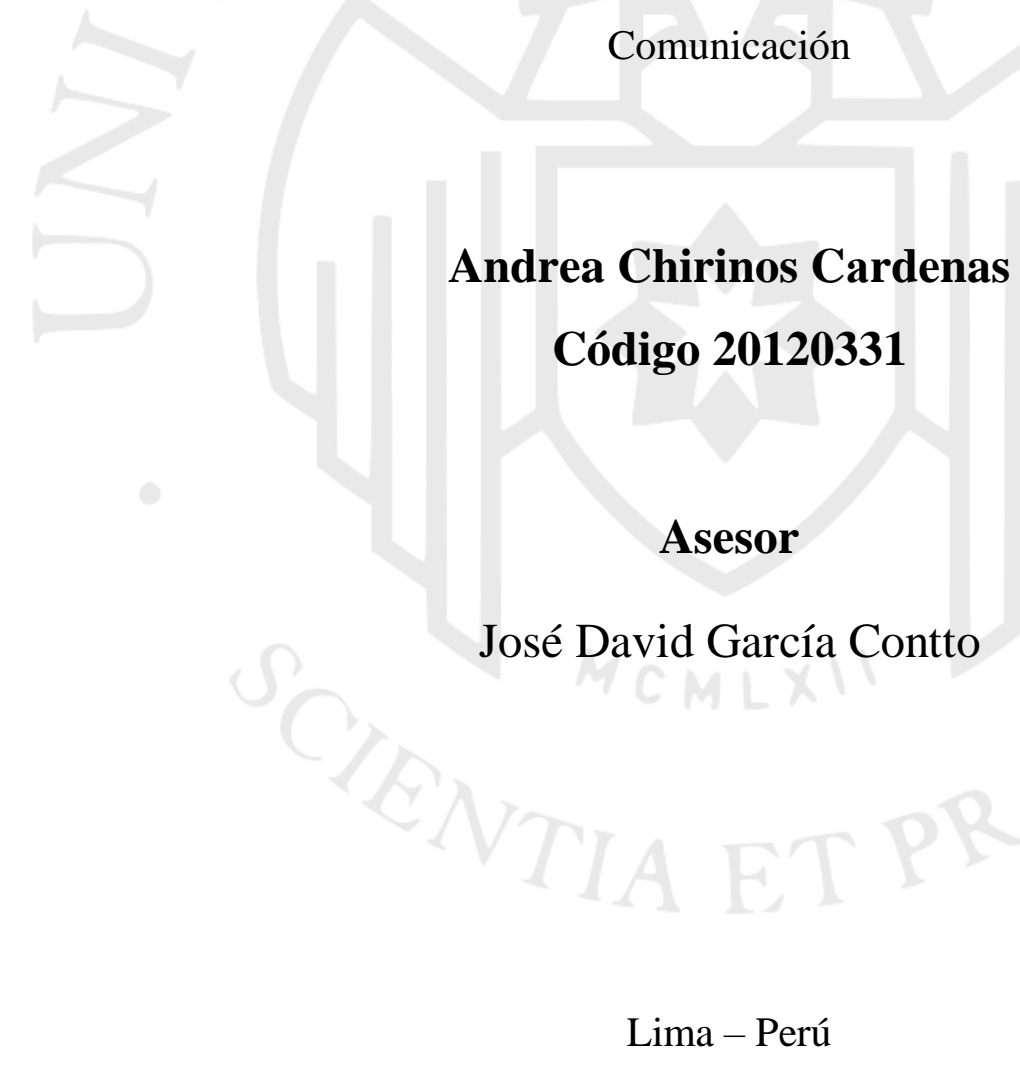

Febrero de 2020 


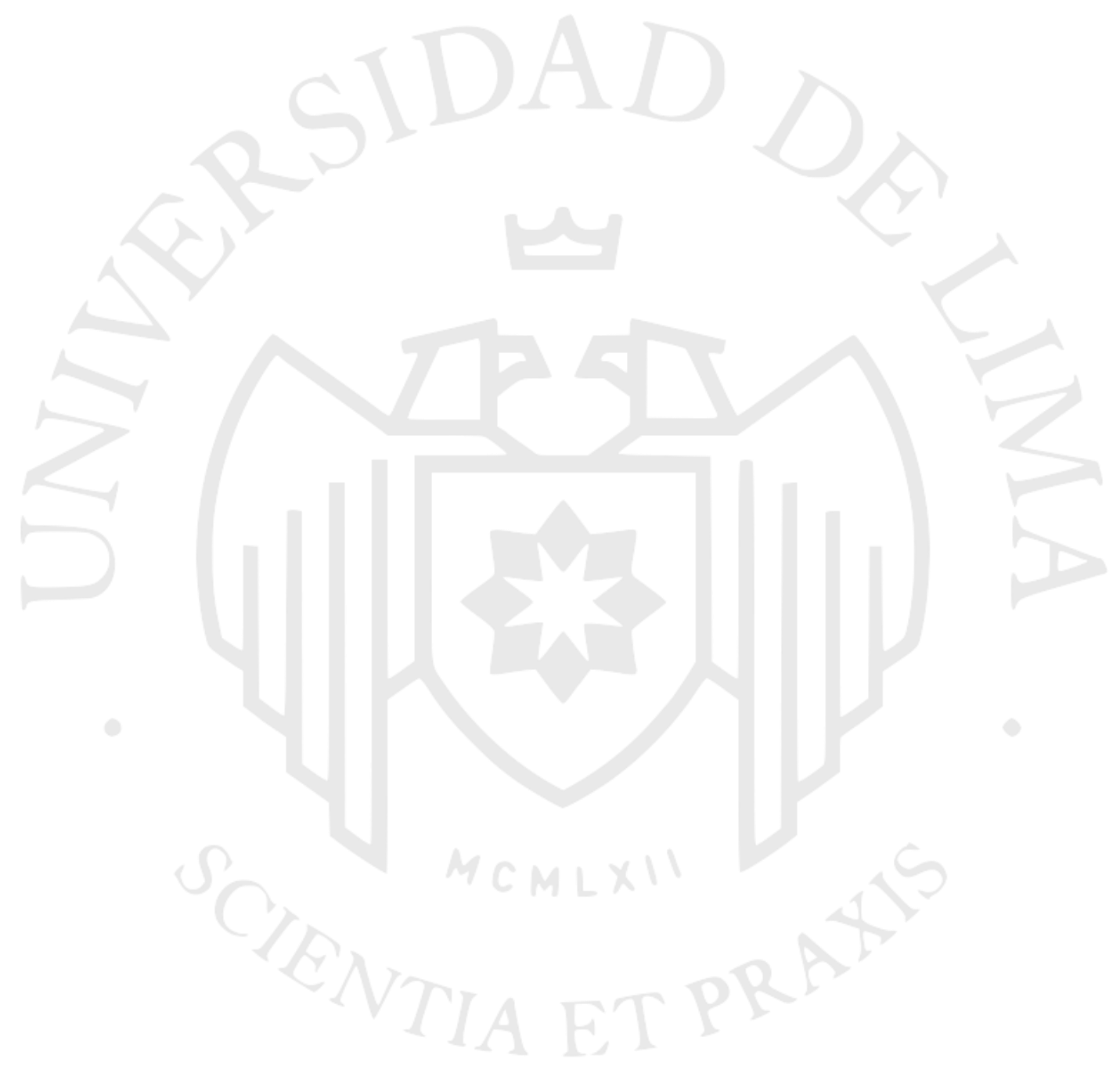


Tras de observar el cielo noche y día Y recorrer todas las líneas De la pampa terrestre Entendió finalmente

Que él también era una línea Más del encaje divino Y que era sólo un monarca De nada 


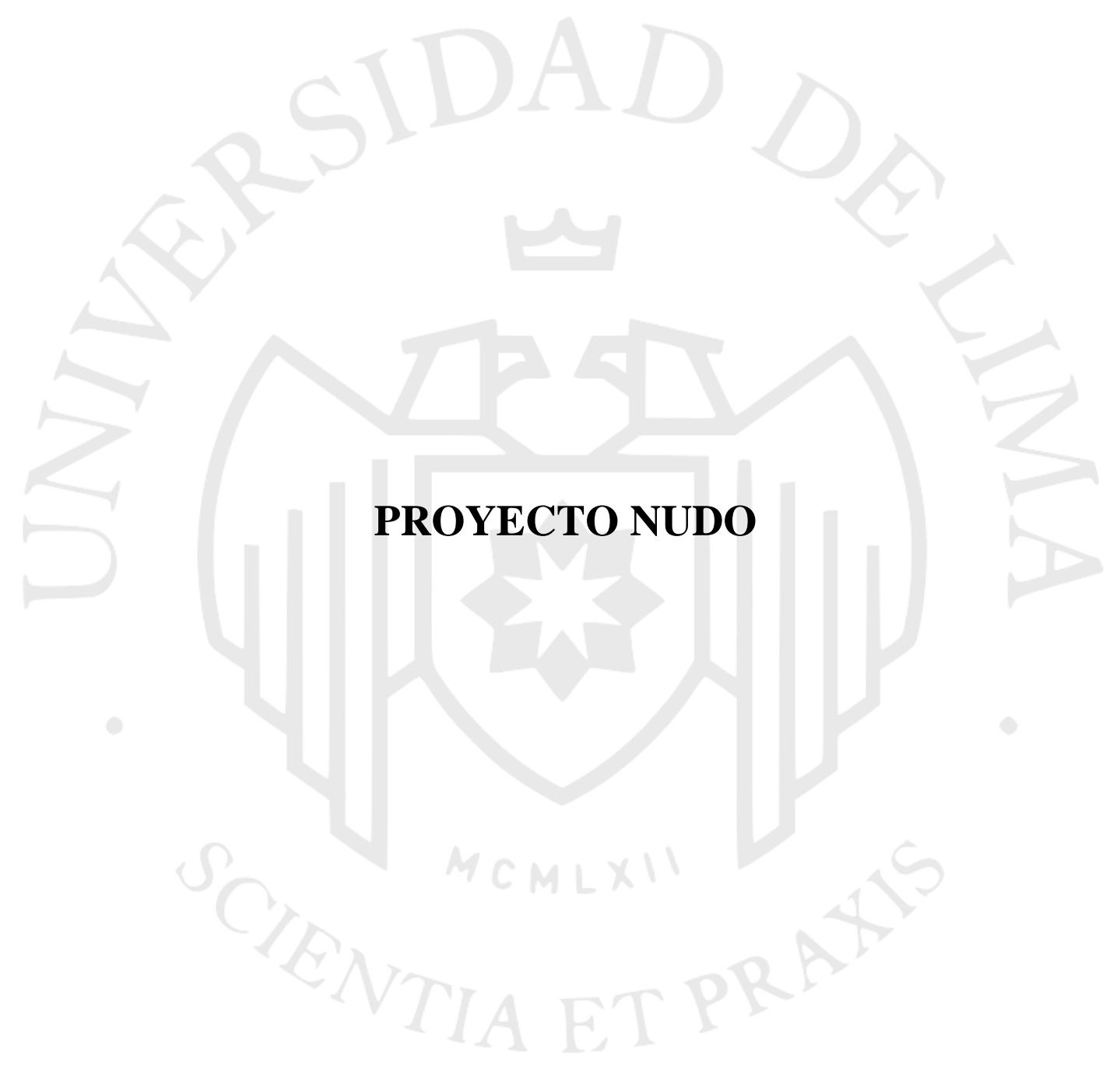




\section{ÍNDICE}

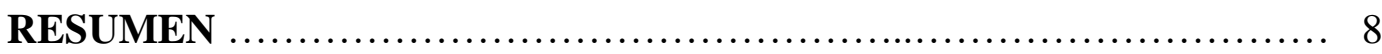

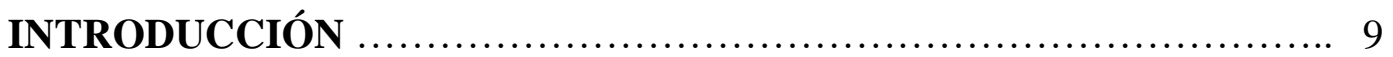

1. ANTECEDENTES DEL TRABAJO ................................. 10

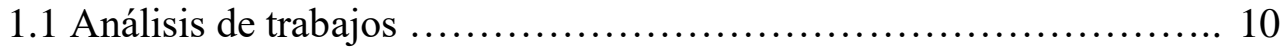

1.1.1 Análisis de artículos y ensayos sobre el "Muro de la Vergüenza" ... 10

1.1.2 Análisis de notas, artículos y ensayos sobre otros muros alrededor del mundo .......................................................... 12

1.1.3 Análisis de exposiciones y archivos fotográficos sobre muros

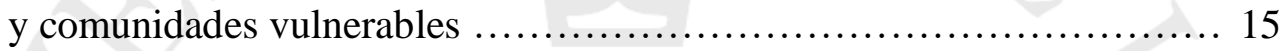

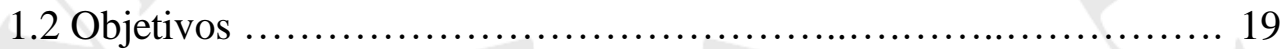

1.2.1 Objetivo Principal ........................................... 19

1.2.2 Objetivos Secundarios ........................................ 19

2. REALIZACIÓN o INTERVENCIÓN ................................ 21

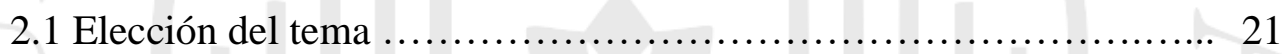

2.2 Elección del nombre ........................................ 22

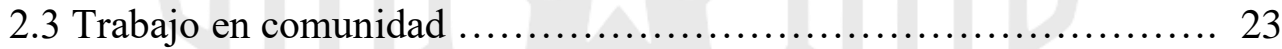

2.3.1 Primera etapa............................................... 24

2.3.1.1 Comunidad El Trébol ....................................... 24

2.3.1.2 Tratamiento fotográfico .................................... 24

2.3.1.2.1 Paisajes ................................................ 24

2.3.1.2.2 Detalles .................................................... 25

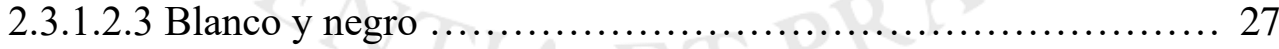

2.3.2 Segunda etapa .............................................. 28

2.3.2.1 Testimonios .............................................. 28

2.3.2.2 Comunidad Vista Hermosa ..................................... 29

2.3.2.3 Tratamiento fotográfico ................................... 29

2.3.2.3.1 Paisajes ................................................ 30

2.3.2.3.2 Retratos .............................................. 31

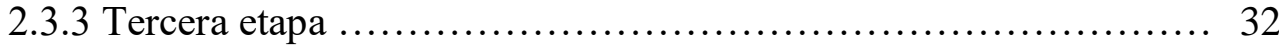

2.3.3.1 Testimonios ................................................ 32 
2.3.3.2 Tratamiento fotográfico

2.3.3.2.1 Paisajes ............................................... 33

2.3.3.2.2 Detalles ............................................... 34

2.3.3.2.3 Retratos .............................................. 35

2.4 Material complementario .................................. 36

2.4.1 Grabaciones ............................................. 36

2.4.2 Video Documental ........................................ 37

2.4.3 Banda Sonora ................................................ 37

2.5 Instalación ..................................................... 38

2.6 Difusión en medios ............................................. 39

2.6.1 Impreso ................................................. 39

2.6.2 Redes sociales ........................................... 39

2.6.3 Mailing y medios digitales ................................... 41

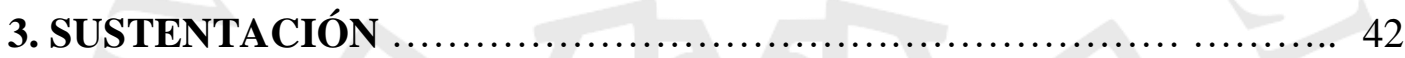

3.1 Tratamiento fotográfico general ............................... 42

3.1.1 Técnica fotográfica ...................................... 42

3.1.2 Técnica en edición ...................................... 44

4. LOGROS Y RESULTADOS ...................................... 46

4.1 Exposición/Instalación fotográfica ............................. 46

4.1.1 Entrevista radial ............................................. 46

4.1.2 Nota de prensa ........................................... 47

4.1 .3 Inauguración ............................................. 48

4.1.4 Conversatorio en Espacio La Sala ........................... 49

4.1.5 Presentación en la Universidad Nacional de Ingeniería ........... 50

4.1.6 Participación en la obra teatral "Muros" ...........................51

4.1.7 Exposición fotográfica en la comunidad El Trébol .................. 51

4.2 Méritos ........................................................... 54

4.2.1 Cualitativos ................................................ 54

4.2.2 Cuantitativos ............................................. 54

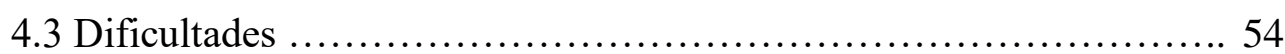

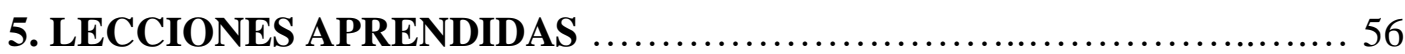

5.1 Aprendizaje ............................................. 56

5.1 .1 Profesional ............................................... 56 
5.1.2 Personal ...................................................... 56

5.2 Recomendaciones ............................................ 57

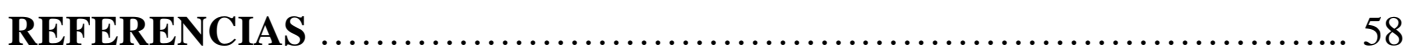

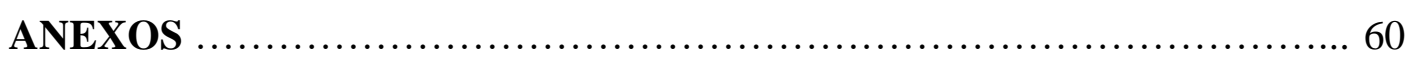




\section{RESUMEN}

El Proyecto Nudo nace con la intención de intervenir en las comunidades adyacentes al conocido "Muro de la Vergüenza", un extenso muro de cemento que se ubica, entre otros distritos, en el medio de Casuarinas y Pamplona Alta. Busca exponer su historia y cómo, con el paso del tiempo, se ha logrado tangibilizar la desigualdad y perpetuar el gran contraste que existe, y siempre ha existido, entre los sectores sociales de la capital del Perú.

Se llevó a cabo un trabajo fotográfico que inició a comienzos de setiembre del 2016 hasta mediados de febrero del 2017. En esas fotografías se hace un recorrido desde el paisaje terroso de las comunidades instaladas en el cerro, hasta la mirada profunda de algunos pobladores que colaboraron con el proyecto. La exposición/instalación final tuvo, además de las fotografías, un corto video documental y algunos elementos de Pamplona.

En enero del 2020, se realizó una segunda exposición en la comunidad "El Trébol", una de las comunidades donde se realizó el proyecto, a modo de celebración por sus 20 años de fundada la comunidad. 


\section{INTRODUCCIÓN}

El proyecto consiste en una exposición e instalación fotográfica que busca mostrar no solo la representación simbólica de un muro que refleja la evidente inequidad social y económica en la capital del Perú, sino también la convivencia generada detrás de este.

El presente informe describe todo el proceso que tuvo el proyecto Nudo, desde la elección del tema hasta la instalación de ciertos objetos claves que fueron extraídos de la comunidad para la exposición de las fotografías. Los antecedentes se eligieron de acuerdo a tres ángulos diferentes, donde se buscó obtener información que sea relevante tanto como para la investigación, como para la realización posterior de las fotografías. El primer ángulo se centra en los documentos que tratan específicamente del famoso "Muro de la Vergüenza”, que representa el protagonista, por así decirlo, de la exposición. El segundo ángulo busca recolectar todo tipo de información existente sobre los muros que habitan alrededor del mundo, donde la división de personas y sus distintas clases sociales, es lo que prima. Finalmente, el tercer ángulo recopila trabajos fotográficos relacionados a muros y comunidades vulnerables. 


\section{ANTECEDENTES DEL TRABAJO}

\subsection{Análisis de trabajos}

\subsubsection{Análisis de artículos y ensayos sobre el "Muro de la Vergüenza"}

El polémico muro que separa a ricos y pobres en Lima - Pierina Pighi (2015)

El artículo periodístico publicado hace poco más de cuatro años por Pierina Pighi en BBC Mundo, narra, de manera un tanto superficial, los verdaderos motivos y situaciones que existen alrededor del famoso "Muro de la Vergüenza". En ese caso, la vergüenza queda sujeta a distintas opiniones, las cuales varían muchísimo entre las respuestas de los habitantes de Casuarinas y los vecinos de Pamplona Alta. Es un contraste inevitable.

Pigui (2015) cuestiona el motivo que causó el levantamiento del muro haciendo hincapié entre posiciones bien marcadas. Una que se sostiene bajo la necesidad de evitar invasiones mientras busca resguardar la seguridad de los propietarios y, por otro lado, otra que ahonda en la evidente discriminación y segregación que representa ese pedazo de pared. Las preguntas quedan a merced del que las lea, lo que da paso a diversas conclusiones sobre si debe existir o no el muro. 
El artículo contiene datos relevantes sobre la situación, sin embargo, no se libra de brindar información errónea, como es indicar de forma general que en pamplona no cuentan con servicios de luz ni agua. En ciertas comunidades de Pamplona, y de forma muy limitada, si cuentan con estos servicios. Está claro que resulta más impactante indicar de golpe la ausencia de estos servicios básicos.

\section{Grupos sociales diferentes en aislamiento voluntario: Sobre la producción de nuevas formas de segregación socio espacial entre los distritos de Santiago de Surco y San Juan de Miraflores - Manuel Santos Arias (2011)}

La tesis realizada en el 2011 por Manuel Santos Arias, egresado de la Universidad Nacional Mayor de San Marcos, introduce un concepto indispensable para tratar el tema: Segregación.

La segregación representa la estrategia que se utiliza con el fin de distanciar unos grupos sociales de otros, donde cabe resaltar la diferencia que existe respecto a recursos urbanos entre estas dos áreas. La segregación existe en Lima, y dentro de esta, se puede hablar de un espacio de micro-segregación en los límites de los distritos de San Juan de Miraflores y Santiago de Surco donde, tanto pobladores como el gobierno distrital, han producido segregación socio-espacial, un proceso que resulta en una aglomeración territorial de grupos sociales diferentes en un mismo espacio urbano, en este caso, en un mismo cerro.

Gracias a herramientas de medición utilizadas en esta investigación, se llegó a la conclusión que existe la concentración de la élite limeña en barrios como Las Casuarinas, La Planicie, Las Lagunas de La Molina, entre otros, así como la existencia de una clase media que funciona como área de amortiguamiento social y que, en ciertas ocasiones, impide o frena la continuidad entre barrios pobres y ricos. El muro es la prueba fehaciente para visibilizar una afirmación que acompaña a la capital del Perú: las barreras sociales y raciales aún perduran. 
1.1.2 Análisis de notas, artículos y ensayos sobre otros muros alrededor del mundo

Vergüenza de vivir donde vivo: Ideas para una re-conceptualización de la segregación residencial socioeconómica - Susana Cortéz (2008)

El artículo de la chilena Susana Cortés publicado en la Revista de Antropología Iberoamericana, narra sobre cómo Santiago, capital de Chile, se caracterizó por abordar un patrón distributivo de segregación residencial socioeconómica a gran escala, donde lo que resalta, incomoda y se critica actualmente es la falta de espacios urbanos de contacto entre habitantes de diferentes estratos sociales.

Sin embargo, esto ha ido cambiando poco a poco en los últimos 20 años, ya que la existencia de segregación residencial se ha acortado y la distancia entre familias de bajos y altos recursos ha disminuido en lugares como campamentos y periferias. Ahora todos terminan siendo vecinos de condominios cerrados.

Cortez (2008) cuestiona este fenómeno para determinar si debe ser considerado como una tendencia, o si solo se trata de casos aislados. Cuestiona también los efectos posteriores que este cambio tendrá en la ciudad, mientras invita a pensar en nuevas alternativas de interacción e integración social (p. 428).

El artículo toma como modelo el caso de la comuna de Peñalolén, donde estas interacciones se mantienen utópicas y la cercanía física se mantiene en eso mismo, algo muy lejano. Asimismo, menciona que “dentro de la segregación residencial, forma parte más de una segregación socioeconómica, y donde las diferencias de un sector y otro en educación, salud y recreación aumentan la brecha entre estos" (Cortéz, 2008). 
Ceuta y Melilla: gestión fronteriza, derechos humanos y seguridad - Pietro Soddu (2006)

Otro ejemplo de división fronteriza con ciertas disparidades sociales, viene a ser el caso de las ciudades españolas Ceuta y Melilla, ubicadas al norte del continente africano. Este muro es conocido como la Valla de Ceuta. Una doble barrera física de 8 kilómetros de extensión y 6 metros de altura separa España y Marruecos con el propósito de frenar la inmigración ilegal y el contrabando comercial. Esta frontera no sólo divide estos dos países, sino también y con mayor importancia, continentes.

Durante mucho tiempo, se luchó por erradicar las diferencias culturales, sociales y económicas que existen en ambos territorios, sin embargo, con el incremento del flujo migratorio que hubo a inicios de los 90 's, la barrera intensificó sus políticas anti-migratorias, lo que ocasionó que muchas personas intentasen lo posible e imposible por cruzar ese muro, incluso poniendo en peligro sus vidas.

La convivencia pacífica en la frontera se vio alterada y derrotada por el "miedo de invasión" que empezó a cobrar fuerza en la sociedad española, mientras que muchas personas seguían intentando cruzar la frontera a modo de encontrar mejores oportunidades y calidad de vida al otro lado del muro.

Más allá del muro: La condición urbano-territorial del límite en América Latina Enrique Naranjo (2016)

Este artículo toma la existencia del límite como elemento fundamental dentro de en lo que a "ciudad" concierne. Ya sea de forma explícita o implícita, "no deja de ser un elemento simbólico para la construcción del espacio urbano contemporáneo" (Naranjo, 2016). 
Los conceptos se tornan inestables y se presentan, nuevamente, opiniones diversas ante este límite impuesto, tal como sucede en la capital del Perú. Como menciona Naranjo (2016), desdibujar los límites no consiste en derretir estructuras sólidas, sino, es más un construir espacios intermedios, ambiguos y complejos que ayuden a desarrollar identidades flexibles y versátiles que respondan a las numerosas mutaciones que sufren en el tiempo (p.13).

En Latinoamérica, el tema de los muros y las divisiones sociales que se tangibilizan, demuestran la fuerte desigualdad que no deja de existir, sin embargo, se puede hablar de desdibujar los límites, asumiendo primero la necesidad de entender que la destrucción de los muros no es una opción.

Según Naranjo (2016):

Desdibujarlo significa resaltar su presencia, evidenciarlo más que ocultarlo, para después diluir su capacidad física. $\mathrm{Si}$ se aborda el límite desde arquitecturas que potencien cada lado, se convertirá en un elemento segregador que reforzará aún más la condición de borde. No cabe, por tanto, reforzar la identidad de cada lado por separado, sino que es necesario que el límite, como espacio intermedio, sea el que adquiera esa capacidad de refuerzo (p.21).

Esto nos permite comprender que no se puede optar por algún tipo de solución a largo plazo, es decir, que la destrucción física del muro no es la única solución. El cambio está en los habitantes de cada lado del muro, en su deseo de llegar a un acuerdo y de abordar sus condiciones de manera empática.

Espacios en conflicto: Un límite proyectado a través de un muro - Luis San Fillipo (2012)

En este ensayo se evalúan tres espacios de frontera: México y Estados Unidos, las favelas de Río y los partidos de San Isidro y San Fernando. La existencia de un 
elemento relevante y repetitivo en la historia de la creación de ciudades y sentido de ciudadanía es, nuevamente, el muro.

San Fillipo (2012) está al tanto de la naturalización de su existencia que se ha venido dando. Se considera "algo dado e inmutable", y aquello evita poder nombrarlo como lo que es: una línea divisoria; y mucho menos, a interrogarlo desde el rol de quien lo produce como producto de sus propios valores, como menciona el autor. Así, se plantea la alternativa de darle un rostro al que convive con este límite, pues, al fin y al cabo, eso hace que tome forma la ciudad (p.94).

\subsubsection{Análisis de exposiciones y archivos fotográficos sobre muros y comunidades} vulnerables

Lazos de color: Nudos de Jorge Eduardo Eielson - Martha Canfield (1991)

Eielson, que fue un poeta y pintor, tuvo como mayor símbolo de su trabajo al nudo, tanto aquellos que existen físicamente, como aquellos que surgen de interpretaciones. El artículo escrito por Martha Canfield plasma la obra de Eielson en todo su esplendor, desde el uso de telas para formar los nudos hasta la tensión que ellos generan.

El trabajo de Eielson sirvió para canalizar la idea del muro como algo simbólico y darle un nombre que diga más de lo que se puede observar. Nudo es el conector de la exposición, un vínculo irónico entre dos clases sociales que comparten el cerro de forma tan cercana y tan distinta a la vez.

Exposición Permanente - Lugar de la memoria, la tolerancia y la inclusión social (LUM) (2016) 
La exposición permanente del LUM sirvió de referencia para el planteamiento de proyecto por su variedad de contenido, su calidad de información y la forma en la que se ordena el espacio para guiar al espectador en la narración cronológica de la época del terrorismo y sus víctimas, proponiendo espacios interactivos como videos, retratos, audios e imágenes.

\section{Cantagallo - Fuera de Foco (2017)}

Fuera de foco es un estudio fotográfico que busca crear conceptos e historias a través de distintos proyectos para poder re-interpretar la realidad de distintas formas. En su página web, cuentan con una sección de Salidas Fotográficas y en esta están las fotos de Cantagallo, un asentamiento shipibo ubicado en el distrito del Rímac. La sección cuenta con tan solo 4 fotografías que retratan la vida de los niños shipibos en su comunidad.

Son fotografías llenas de luz e inocencia que retratan la realidad como tal, sin necesidad de recurrir a la pena y lástima que algunos espacios evocan, tal como se busca lograr en Nudo. Las fotografías no cuentan con alguna descripción o título, lo deja al criterio del visitante.

Éxodo imposible - Marco Garro (2015)

En una edición del Museo de Arte Contemporáneo (MAC), se expusieron dos trabajos de Marco Garro sobre dos ciudades en la sierra del Perú: Cerro de Pasco y La Rinconada. Garro cuenta la historia de ambos pueblos a través de la fotografía, a través del contraste remarcado, los colores intensos, los rasgos de las personas, escenarios vacíos, entre otros puntos importantes que pueda tener una imagen. La combinación 
perfecta y balanceada entre el ser humano y su entorno da pie a que se narre una buena historia.

Vivir en la tierra - Andy Goldstein (2012)

El surgimiento de asentamientos humanos no son un fenómeno que sólo se da en el Perú, sino que recorre América Latina. Andy Goldstein es un fotógrafo argentino que realizó el proyecto fotográfico Vivir en la Tierra. Durante casi 25 años, viajó por distintos países en Latinoamérica como Brasil, Chile, Colombia, Costa Rica, Ecuador, El Salvador, Guatemala, Haití, Honduras, Perú, entre otros, tomando fotografías al interior de viviendas de los asentamientos que iba encontrando y a sus habitantes, quienes aceptaron ser retratados en su propio espacio.

Este proyecto cuenta con la veracidad exacta para narrar su paso por Latinoamérica, el respeto que les tiene a las familias que conoció, cómo estas aceptaron contribuir con su proyecto y la representación de la precariedad con la que viven miles de personas en el Continente Americano. Goldstein contó también con la ayuda de la ONG Techo para su ingreso en las comunidades. Al igual que Goldstein, para llevar a cabo Nudo, se aprovechó el reconocimiento que tiene TECHO dentro de las comunidades para llegar a ellas con confianza e identidad.

Conductas Urbanas - Oscar Pacheco (2012)

Este libro es la compilación de muchos años de fotografía testimonial. Son los momentos y las situaciones más banales o más representativas, los que le dan forma a la narración de una historia fotográfica, y en este libro aquello es fielmente registrado. 
Pacheco da relevancia, más allá de la arquitectura de los barrios altos, a su gente. Aquella que fue y es producto de diversas mezclas que se integran en un mismo espacio por la precariedad de su condición social. Es a esa parte de la población a la que apunta el proyecto $\mathrm{Nudo}$, con la diferencia que esta vez hay un muro de por medio.

Existe cierta ambición por rescatar, a través de la fotografía, el entorno cultural y socioeconómico de la ciudad, de sus habitantes y de sus comportamientos y manifestaciones. Asimismo, Pacheco optó por usar blanco y negro en toda la colección, como parte quizás de su propuesta melancólica.

Wall - Josef Koudelka (2015)

Este fotógrafo checo nacionalizado francés tomó, desde 1986, fotografías con una cámara panorámica. Su interés se centró, como su trabajo profesional en sí, en territorios devastados a causa de conflictos armados.

Este trabajo, documenta los muros y alambras que forman la frontera de Cisjordania. Los muros se levantan formando una frontera física y a la vez, dándole significado a su existencia. Se trata de un paisaje creado por el hombre en su máxima expresión: sujeto de creación y destrucción del mundo.

Koudelka encontró la manera de representar los espacios y llegar a los conceptos de los cuales se ha hablado anteriormente. Las fotografías comunican sin necesidad de ser explicadas a mayor detalle. Además, tomó como eje principal la existencia de un objeto físico, ostentoso y producto del hombre a modo de dividir lo que ni siquiera le pertenece, el espacio. 


\subsection{Objetivos}

\subsubsection{Objetivo Principal}

Exponer la existencia del muro de la verguenza y la vida junto a este, que se ubica en Pamplona Alta en el distrito de San Juan de Miraflores, a personas de nivel socioeconomico A y B del distrito de Miraflores y alumnos de la Universidad de Lima.

\subsubsection{Objetivos Secundarios}

\subsubsection{Primer Objetivo Secundario}

Retratar la realidad que se vive en los asentamientos humanos situados al otro lado del muro mediante fotografías.

\subsubsection{Segundo Objetivo Secundario}

Recopilar testimonios de los habitantes que habitan junto al muro, y exponerlo en un video documental de corta duración. 


\subsubsection{Tercer Objetivo Secundario}

Invitar a reflexión a los invitados de la muestra, personas de nivel socioeconómico A y B del distrito de Miraflores y alumnos de la Universidad de Lima, a través de un conversatorio.

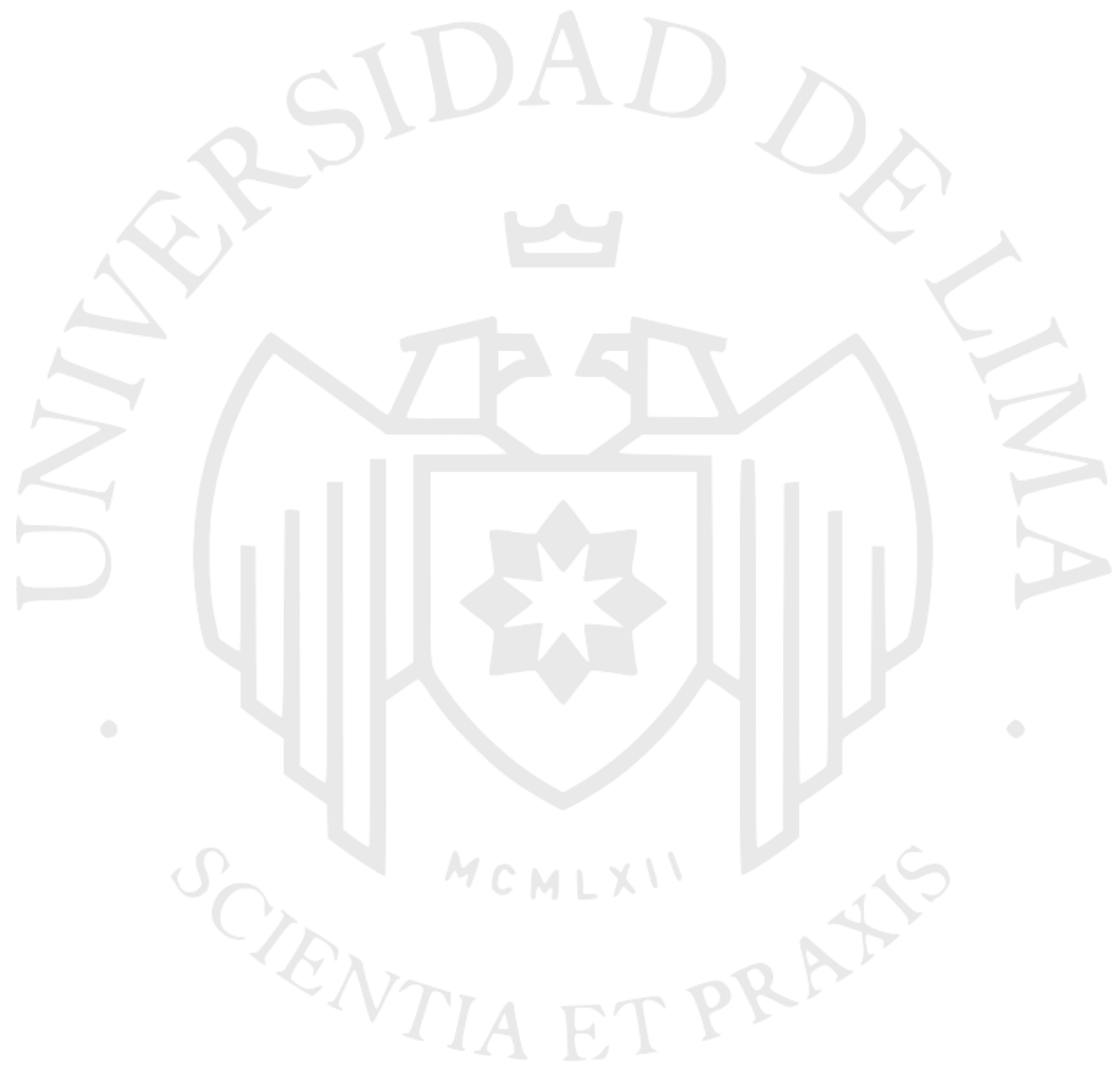




\section{REALIZACIÓN o INTERVENCIÓN}

\subsection{Elección del tema}

La elección del tema surge con un cuestionamiento e inevitable indignación hacia la existencia de aquel muro ubicado en la cima del cerro que comparten Casuarinas y Pamplona. Previo a que el proyecto tomara forma o hasta incluso se planteara como proyecto en sí, ya había habido un acercamiento hacia las comunidades vulnerables de aquella zona de Lima. La ONG Techo ofrece programas de voluntariado donde se trabajan proyectos sostenibles a diversas comunidades, una de ellas se llama El Trebol, y Techo había trabajado con ella hacia el 2012, aproximadamente.

La primera visita a dicha comunidad incrementó el interés de dar a conocer lo que sucede a ese lado del cerro. Quedó constancia que la existencia de una pared de cemento, que divide a dos distritos que comparten el cerro y que son notablemente distintos en cuanto a situación económica y social, se había cotidianizado a tal punto que se constituía como una convivencia más resignada que incómoda, y mucho menos un motivo para exigir explicaciones. En Setiembre del 2016, se empezaron a tomar las primeras fotografías del lugar. 


\subsection{Elección del nombre}

La elección del nombre fue variando desde el comienzo. Se buscó jugar con los distintos conceptos y simbolismos que puede tener la palabra muro. En un inicio, el título intentaba explicarse a sí mismo, como, por ejemplo:

“El muro: La representación simbólica de una traba social y comunicacional."

Se quería explicar a través del título la idea, el concepto y el motivo de las fotografías que se presentarían. Se buscaba llevar la atención en el muro para colocarlo como protagonista dentro de la imagen, lo cual nunca dejó de ser, pero con el tiempo y con la experiencia que se iba recolectando de distintas comunidades aledañas, se fueron adhiriendo otros factores como las personas, sus vivencias, su propio habitar.

La elección final del nombre se dio a puertas de la exposición, cuando las fotografías ya habían sido elegidas e incluso, cuando ya estaba tomando forma el corto video documental que iba añadirse al proyecto.

¿Por qué Nudo?

La palabra Nudo tiene diversas definiciones, dieciocho, encontradas en la Real Academia Española, para ser exactos. Se optó por elegir aquellas que mejor interpretaran al muro, tomándolo tanto como un objeto físico como simbólico. Son cuatro las definiciones que, según la RAE (RAE, s.f.), explican lo que es un nudo:

\section{Aspecto central de una cuestión. El nudo de un problema.}

El concepto del que parte el proyecto sería este, donde la existencia de un problema es el punto de partida: La marcada brecha entre las clases sociales que cohabitan en la capital. 
Lazo que se estrecha y cierra de modo que con dificultad se pueda soltar por sí solo, y que cuanto más se tira de cualquiera de los dos cabos, más se aprieta.

La tensión entre estas dos clases sociales, representa el nudo que no se desanuda ni se desajusta porque se sigue jalando de ambos lados, se sigue perpetuando la desigualdad de modo físico y simbólico al continuar aceptándola.

\section{Unión, lazo, vínculo.}

Este lazo que se anuda, representa también un vínculo inquebrantable para ambos lados del cerro. Tomar esta definición es darte la vuelta irónica a la situación, pues el lugar no se va a separar en dos y siempre habrá este punto de encuentro.

\section{Obstáculo, traba, impedimento.}

El muro como un nudo físico que impide o dificulta el tránsito regular entre ambas comunidades. Y también, el muro como un nudo simbólico que dificulta la comunicación entre ellas.

Nudo engloba las muchas y muy diversas definiciones que puedan ir apareciendo en el camino. Se trabajó bajo una premisa que englobaba todo lo que se quería comunicar: Nudo de nudos que busca ser des-anudado.

\subsection{Trabajo en comunidad}

Cuando se habla de Comunidad o Comunidades se habla de uno o varios Asentamientos Humanos. Es un término utilizado mayormente por la ONG Techo, a modo de minimizar las connotaciones negativas que pueden existir alrededor de la palabra "asentamiento". El trabajo en las comunidades comenzó la primera semana de septiembre. 


\subsubsection{Primera Etapa}

La primera etapa fue de reconocimiento del espacio, de la distribución de las viviendas y las áreas comunes.

\subsubsection{Comunidad El Trébol}

El Trébol fue la primera comunidad que se recorrió en una primera visita. Antiguos coordinadores del equipo de TECHO en esa comunidad ayudaron a establecer un primer contacto con algunos miembros de la Junta Directiva. Asimismo, se optó por hacer uso del polo con el logo distintivo de esta ONG, pues existe un reconocimiento de la población hacia el trabajo que esta organización tiene en las comunidades, principalmente, el de ofrecer viviendas de emergencia cada cierto tiempo y de acuerdo a la necesidad de la comunidad en sí. Es en esta comunidad, donde un 90\% de las visitas comenzaban desde el paradero de combis y la entrada de un mercado que tan solo contaba con 4 o 5 stands abiertos para venta, hacia lo alto del cerro. Desde ese punto se podía empezar a subir hacia el muro y recorrer las viviendas posicionadas en el cerro con dificultad.

\subsubsection{Tratamiento Fotográfico}

Las primeras fotografías tienen un aspecto sobrio y des-saturado, lo que permite dar paso a una sensación terrosa e incolora que, a su vez, trasmite suciedad y tristeza en el ambiente. También se hizo uso de la viñeta, una alteración en la foto que oscurece o esclarece los bordes de la imagen, formando un círculo que logra centrar la mirada del espectador. Se optó por usar una viñeta negra. 
Sin embargo, la nostalgia y el aspecto sobrio no conformaban el propósito de la propuesta, por lo que de estas primeras fotografías no quedó ninguna para la exposición. Se buscaba capturar situaciones que narren la vida al otro lado del muro, y no paisajes vacíos que muestren como víctimas a sus habitantes. A continuación, se mostrarán algunas fotografías que conforman la primera selección de las primeras visitas a la comunidad de "El Trébol"

\subsection{Paisajes}
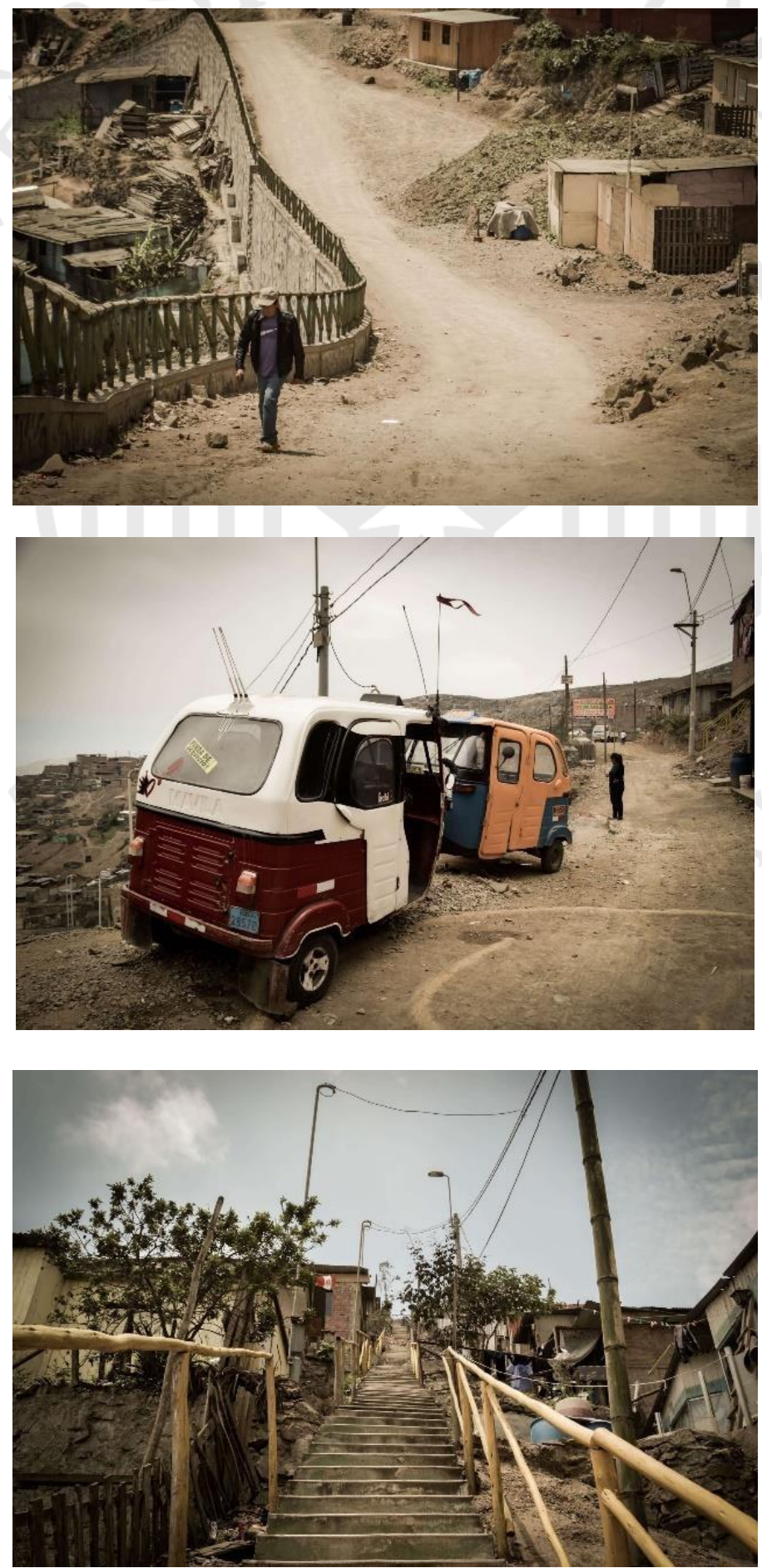


\subsection{Detalles}
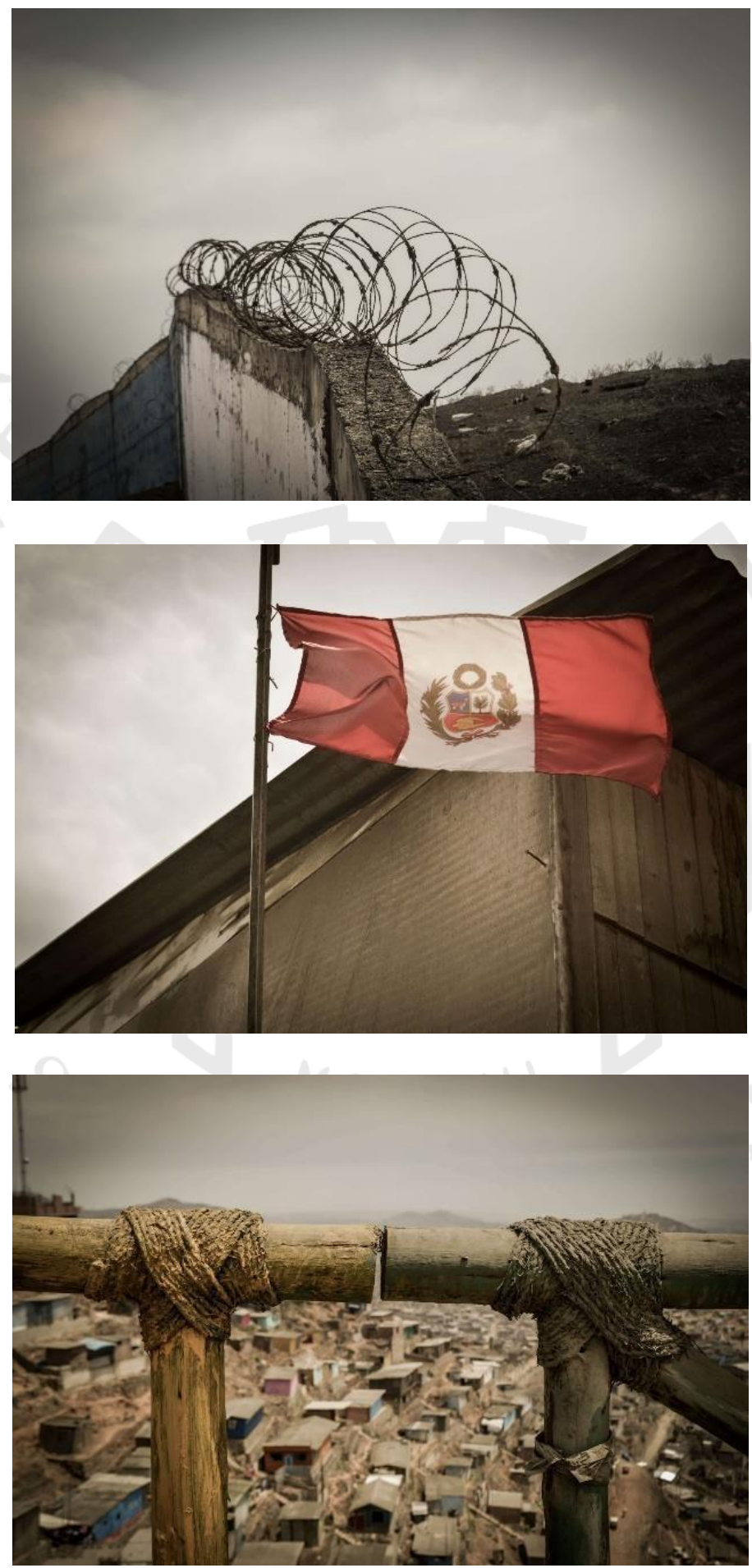


\subsection{Blanco y Negro}
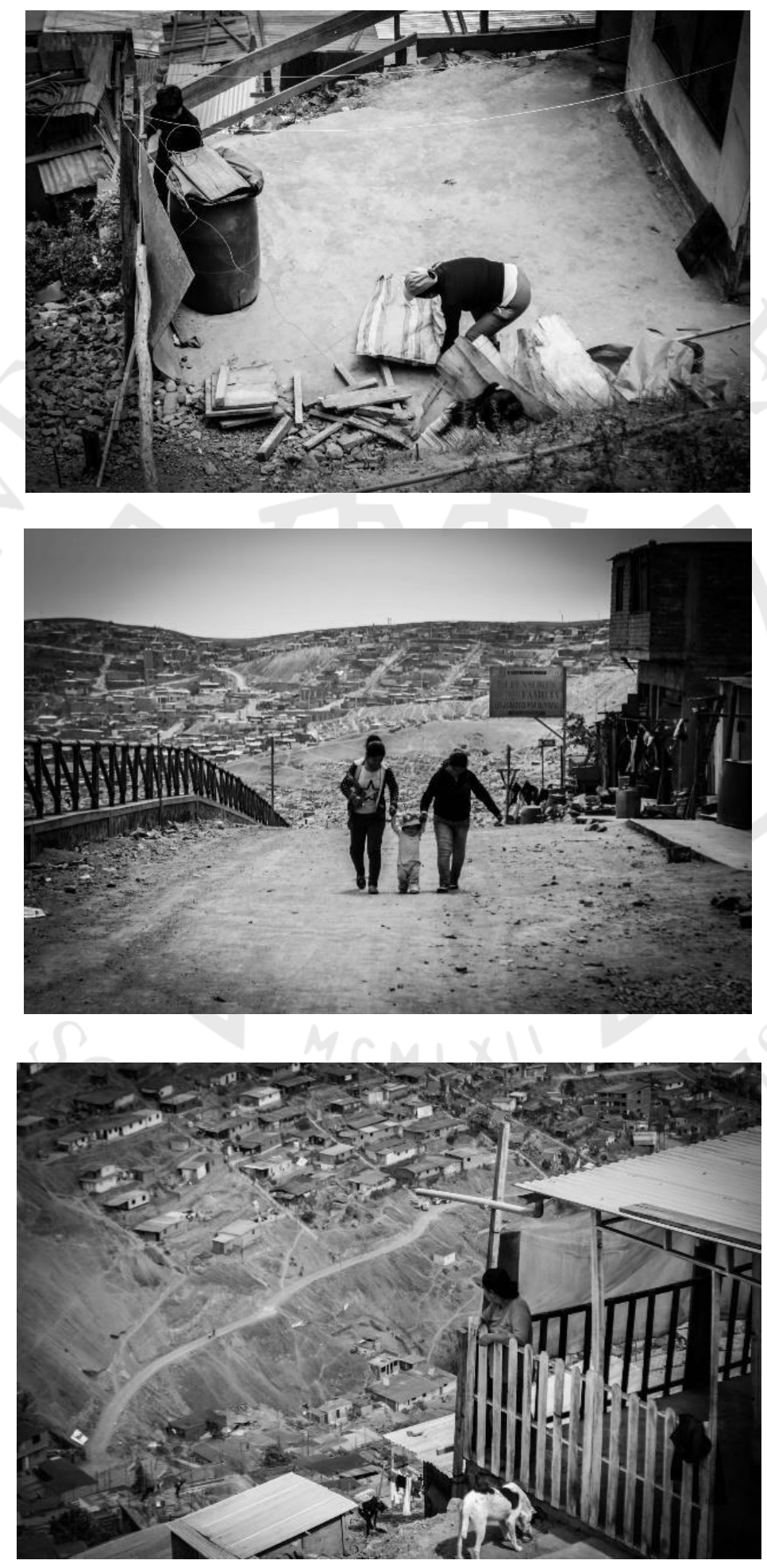


\subsubsection{Segunda Etapa}

La segunda etapa se centró en la gente y en establecer un vínculo tanto con los vecinos de la comunidad como con el espacio donde habitaban. Asimismo, se formó un calendario de visitas con el objetivo de lograr establecer dicha relación de confianza, es decir, que la llegada a la comunidad ya no sea extraña, que haya un reconocimiento por parte de las personas. Se empezó por el muro. Este no podía ser un elemento más, sino que tomaba el lugar que le correspondía: el protagonista.

\subsubsection{Testimonios}

El primer testimonio que se obtuvo fue del señor Octavio Mendoza. Lo primero que le llamó la atención fue la cámara. A partir de ahí, la conversación siguió su curso. La entrevista no fue planificada, de hecho, se realizó mediante la improvisación. Mendoza comentó sobre la situación del agua "allá arriba", lo lento y tedioso que puede ser el trámite para conseguir los permisos requeridos, y también el avance que se hace cada día gracias al apoyo de vecinos organizados que trabajan los domingos en las famosas "faenas" para la mejora de su comunidad.

La segunda entrevista fue a Oscar Leiva, dirigente de la comunidad El Trébol, en ese entonces. Leiva comentó únicamente sobre la existencia del muro. Mencionó que la consecuencia más molestosa sobre la construcción del muro es la dificultad por la que pasan muchos vecinos de Pamplona al encontrarse con este bloque de cemento entre un distrito a otro. 


\subsubsection{Comunidad Vista Hermosa}

A comienzos de noviembre del 2016, se optó por recorrer la distancia de aproximadamente $10 \mathrm{~km}$. que abarca el muro, que cubría muchas más comunidades como la comunidad de Vista Hermosa, en la punta del cerro donde está situada una cruz grande de madera, justo donde termina el muro.

Es justo ahí donde llegan periodistas y fotógrafos a documentar la existencia del muro, hecho que sucede cada tanto y donde la crítica es siempre la misma: La brecha entre ricos y pobres es tan solo la distancia al cruzar de una parte del cerro a la otra. El principal problema con esa declaración es que los reportajes siempre terminan victimizando a los vecinos de Pamplona, lo cual tampoco resulta muy acertado.

La llegada hasta ese punto no tuvo ningún tipo de percances. Los vecinos no cuestionaron si la visita hasta ese punto era parte de una nota periodística o no. El objetivo principal era llegar al punto donde el muro se podía apreciar como línea divisoria del cerro. Es ahí donde la diferencia entre un distrito y otro se realza. El color y la propia distribución del espacio marca un espacio abismal entre una y otra, y eso solo se puede ver desde ese punto más alto o desde un drone.

\subsubsection{Tratamiento fotográfico}

Las fotografías se enfocaron principalmente en los vecinos, en su día a día, en obtener retratos poderosos que narrarán más que el espacio mismo. El principal problema fue que muchas personas posaban ante la cámara, tomando el trabajo entre risas y bromas. Los mejores retratos de la colección son aquellos que no fueron advertidos. Las fotografías de paisaje empezaban a apropiarse del tono sepia y del 
aspecto terroso que resulta tan poderoso, que logra opacar los colores de las casitas sobre el cerro. El cielo gris de Lima, tampoco ayuda a darle vida a las fotografías y se opta por utilizar el recurso del blanco y negro.

\subsection{Paisajes}

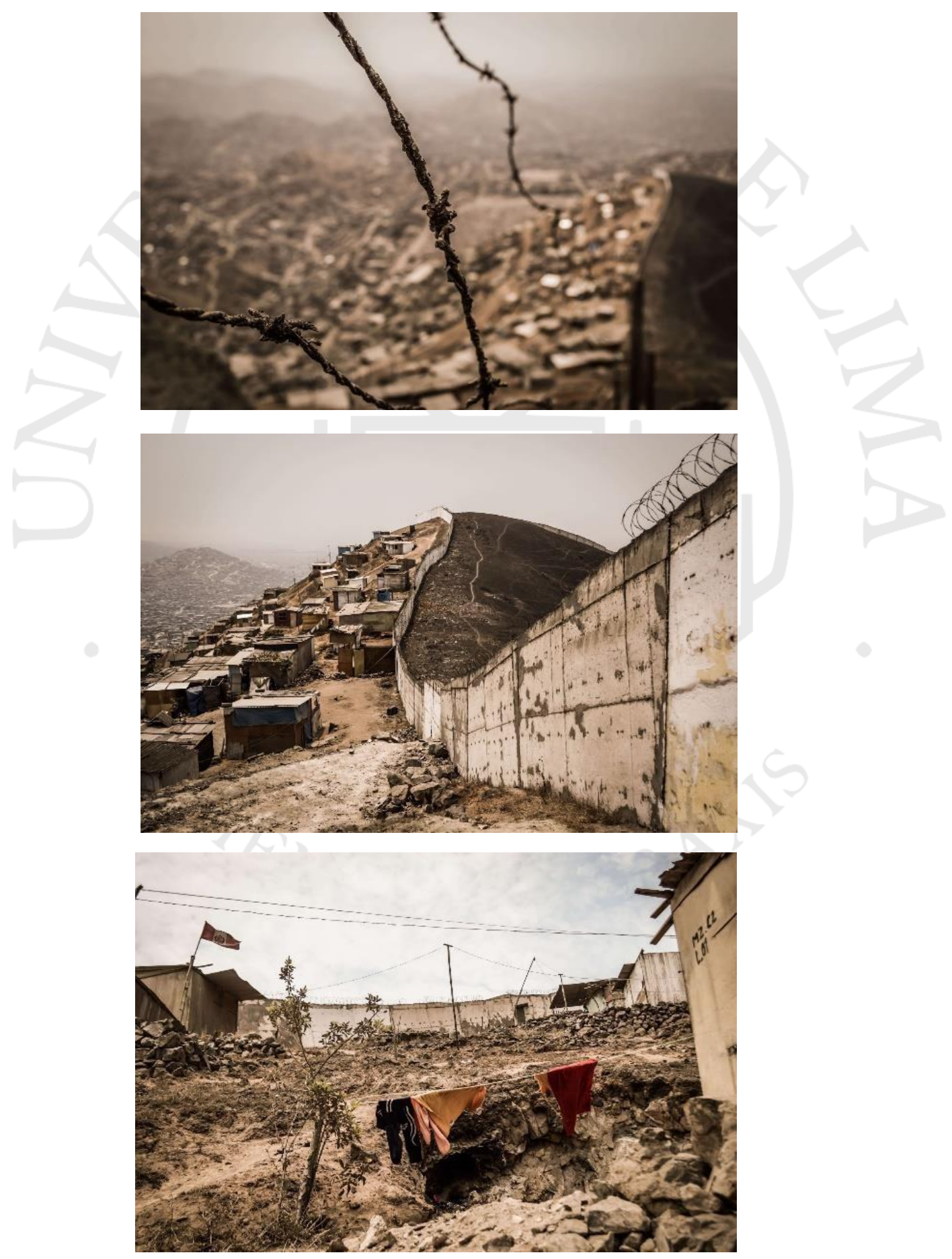




\subsection{Retratos}
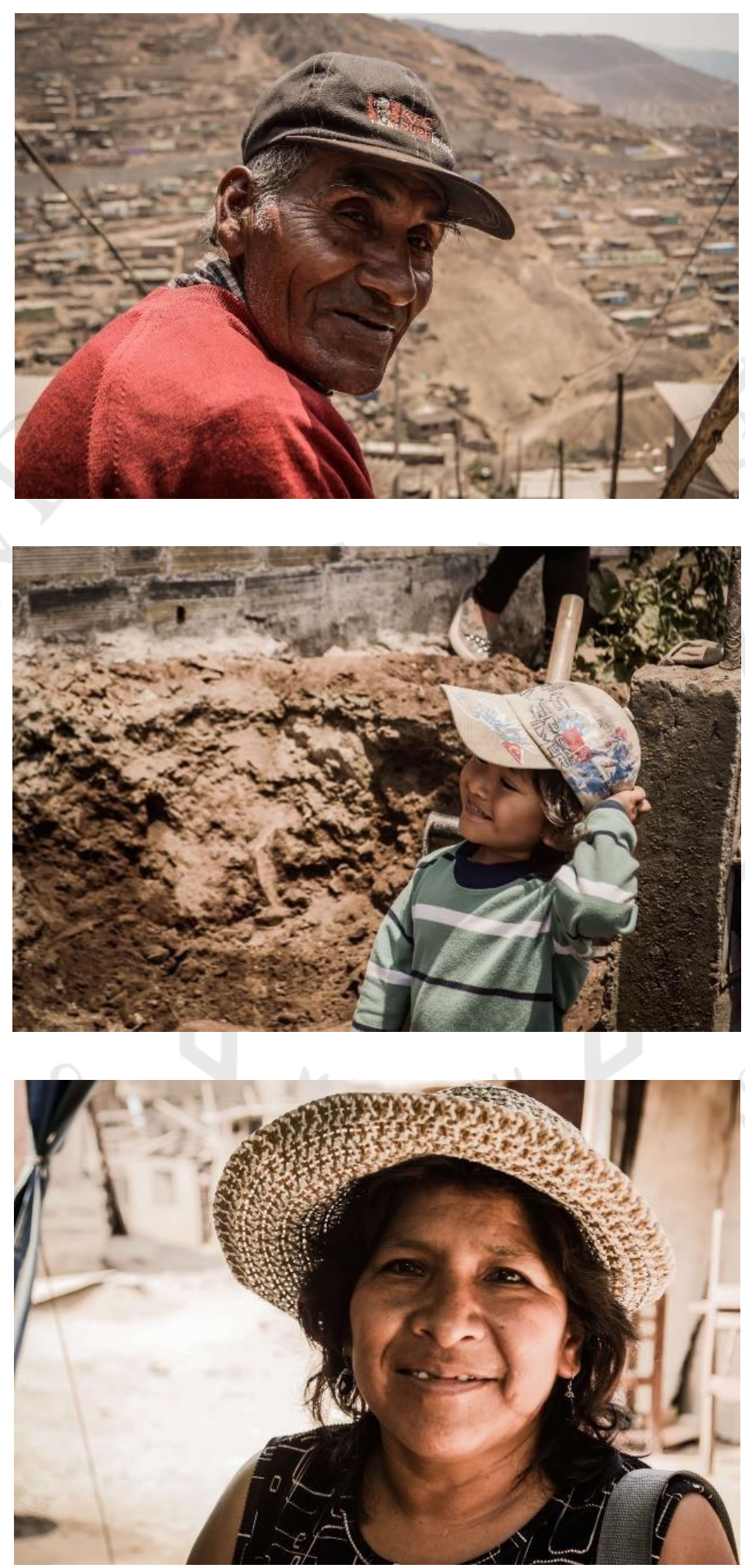


\subsubsection{Tercera Etapa}

Dado que el vínculo con la comunidad ya se había creado, la tercera etapa se enfocó en recorrer más el muro, pasando de comunidad en comunidad. La intención era obtener nuevos testimonios y buscar, dentro de lo que ya se había encontrado, nuevos ambientes y nuevas formas de convivencia con el muro. Dentro de las comunidades adyacentes que se recorrieron se encontraban: Nuevo Milenio, Defensores de la Rinconada y Nadine Heredia.

\subsubsection{Testimonios}

La cantidad de entrevistas que se obtuvieron en esta etapa fue mucho más grande. Fueron dos factores que permitieron eso: la confianza que existía al acercarse a los pobladores, y la necesidad de tener todas las entrevistas posibles para realizar el corto video documental.

Es en esta etapa donde se aprovechó entrevistas anteriores para formular mejor las preguntas alrededor del muro, la situación de la comunidad, el tiempo que viven ahí, la seguridad, entre otras cosas. Es así como se llega a la entrevista con Gerardo Palacios, ex dirigente de la comunidad de Nuevo Milenio, en ese entonces. Con él se conversó de la zona de Casuarinas principalmente y cómo existe una lucha constante para definir a quién le pertenece el cerro.

Buenaventura, un anciano que venía a visitar a su familia desde Ayacucho, también tuvo una entrevista breve donde la conversación llegó hasta la época de terrorismo en Huallanca y lo mucho que se habían visto afectados.

Isidoro, quien estaba quemando una llanta para romper una gran piedra y hacer espacio para su terreno, también tuvo una entrevista. Él conversó sobre el agua, 
su tiempo viviendo ahí y cómo era la vida en general. La entrevista no duró mucho y al instante él ya estaba quemando la llanta y molestando al resto de los vecinos.

Luego se entrevistó a Ever. Su principal interés también fue la cámara y se conversó sobre la escasez de trabajo por la zona y un poco también sobre el muro en sí $\mathrm{y}$ todas las interpretaciones que se dan acerca de este.

Finalmente estuvo Fabiola Rosales, una jovencita que acaba de tener a su primer hijo. Ella se encontraba muy molesta por el fuego que había hecho Isidoro hace unos minutos, observaba desde su balcón el humo negro que botaba la llanta y cómo ensuciaba el paisaje de su comunidad desde lo alto. Ella vivía justo al costado del muro y dio una entrevista larga sobre este, sobre lo que significaba y si debería quedarse.

\subsubsection{Tratamiento Fotográfico}

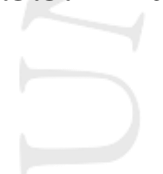

La técnica que se utilizó fue distinta a la que se había usado en un inicio, principalmente por la experiencia obtenida, y también por la influencia de la fotografía periodística sobre un espacio al que ya había recurrido muchísimas veces. Se trabajó más en la composición de las fotografías, buscando simbolismos, líneas y nudos.

\subsection{Paisajes}

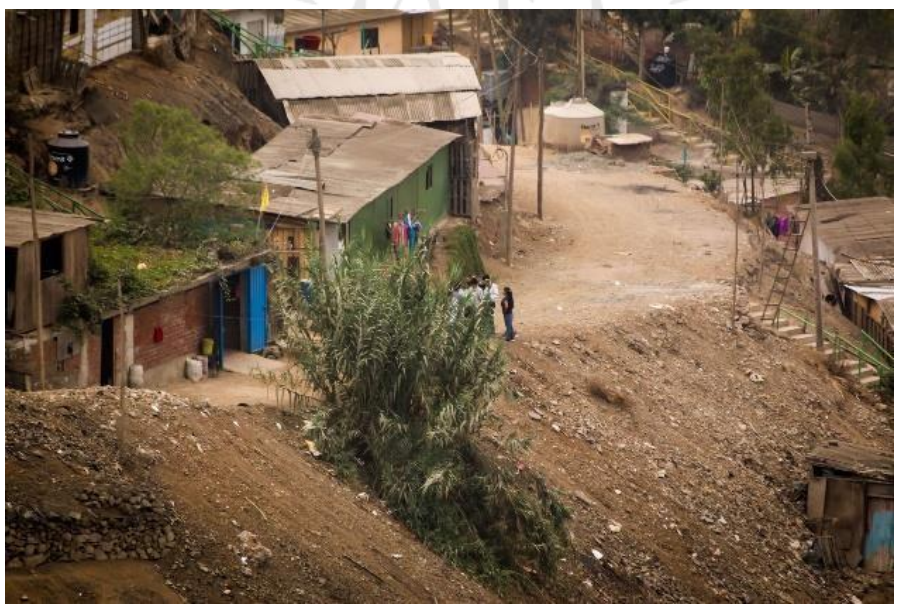



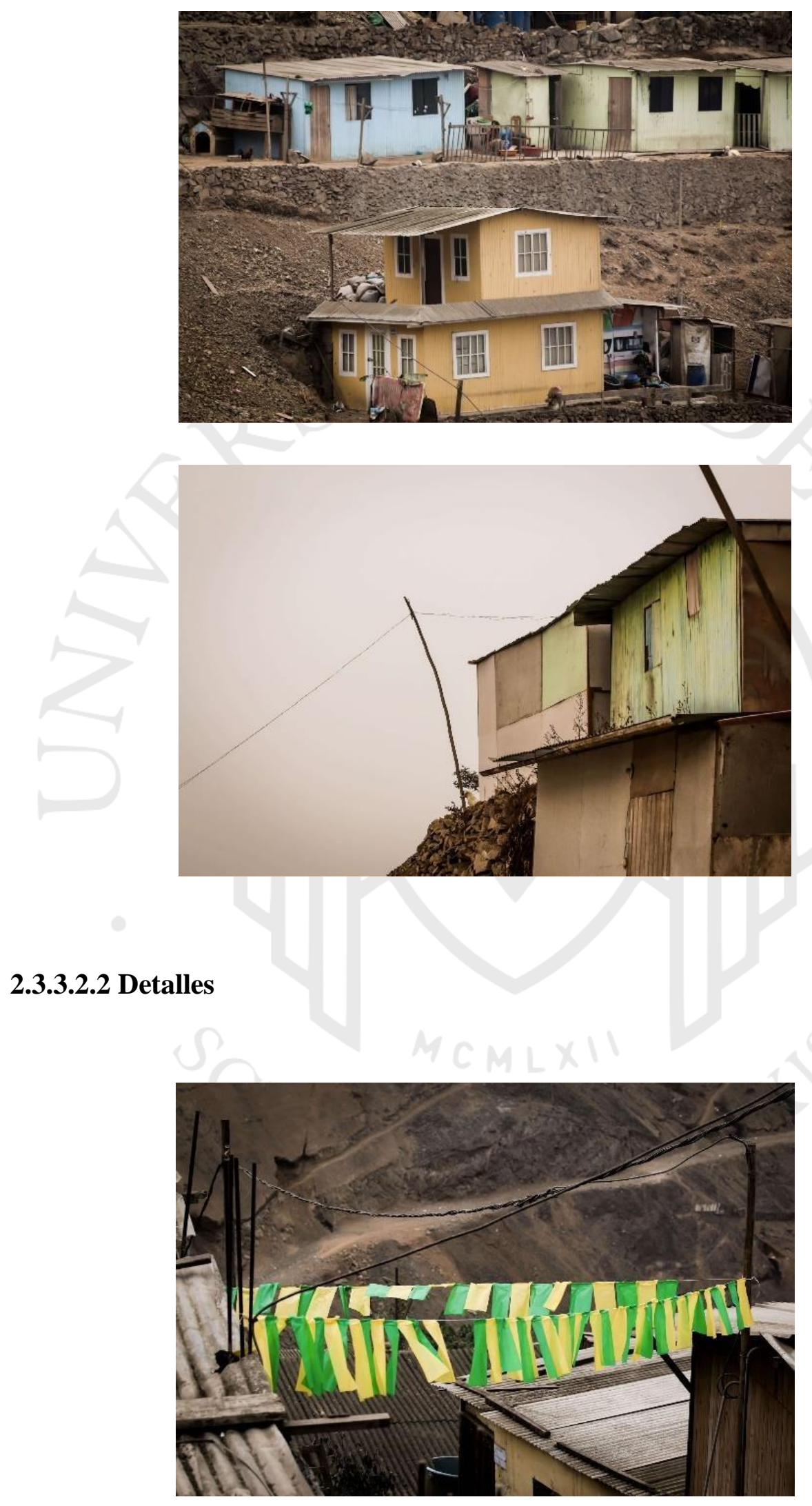

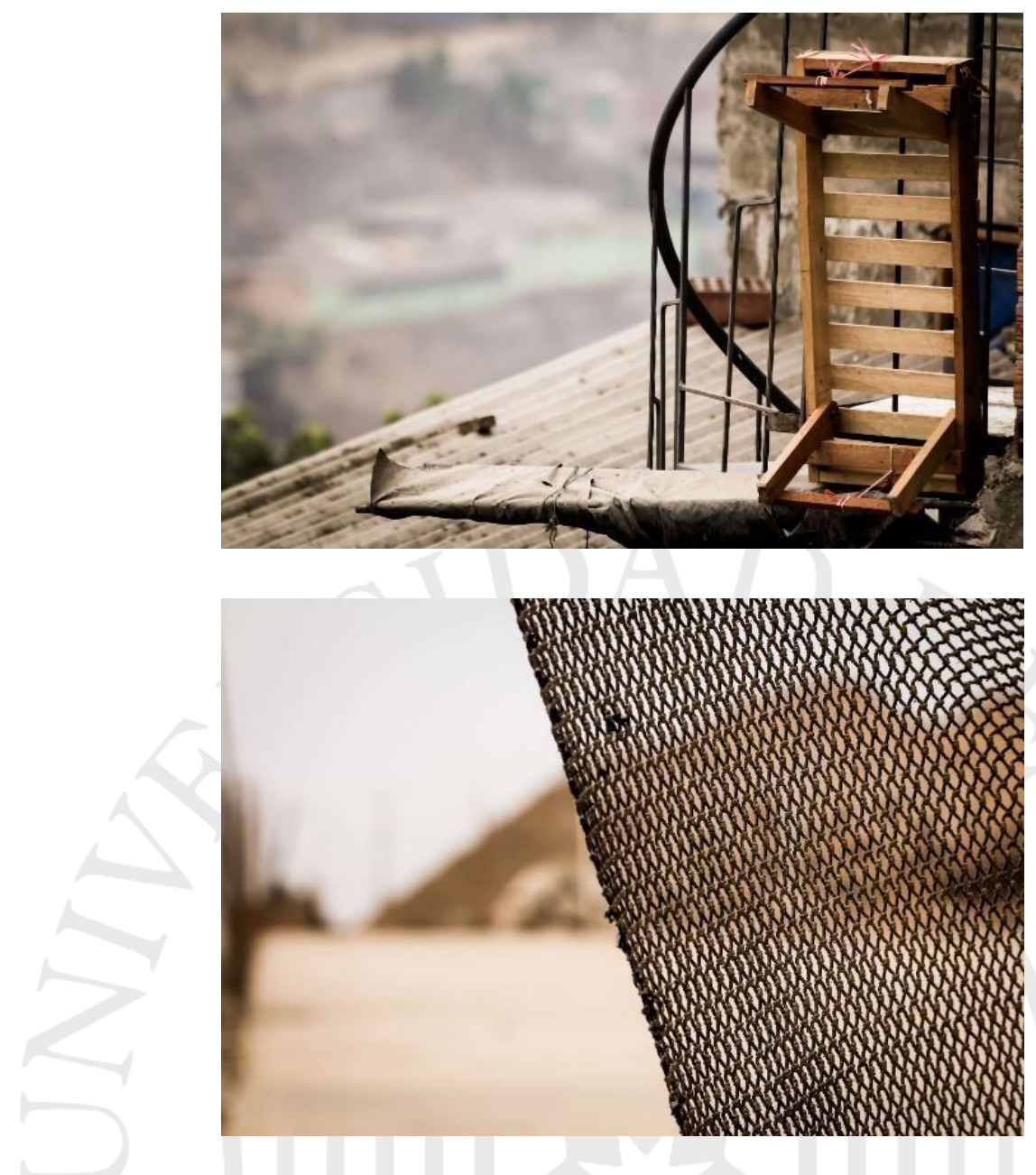

2.3.3.2.3 Retratos

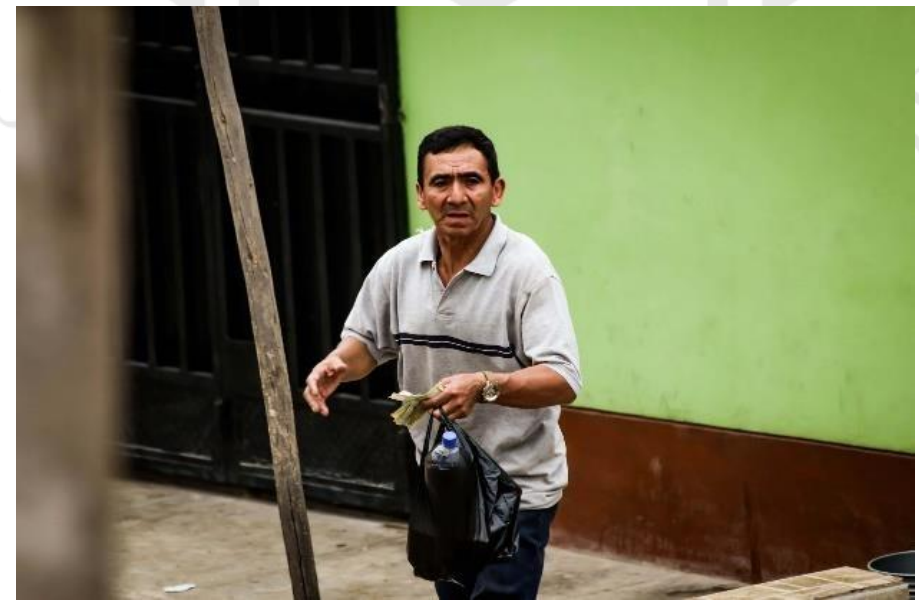



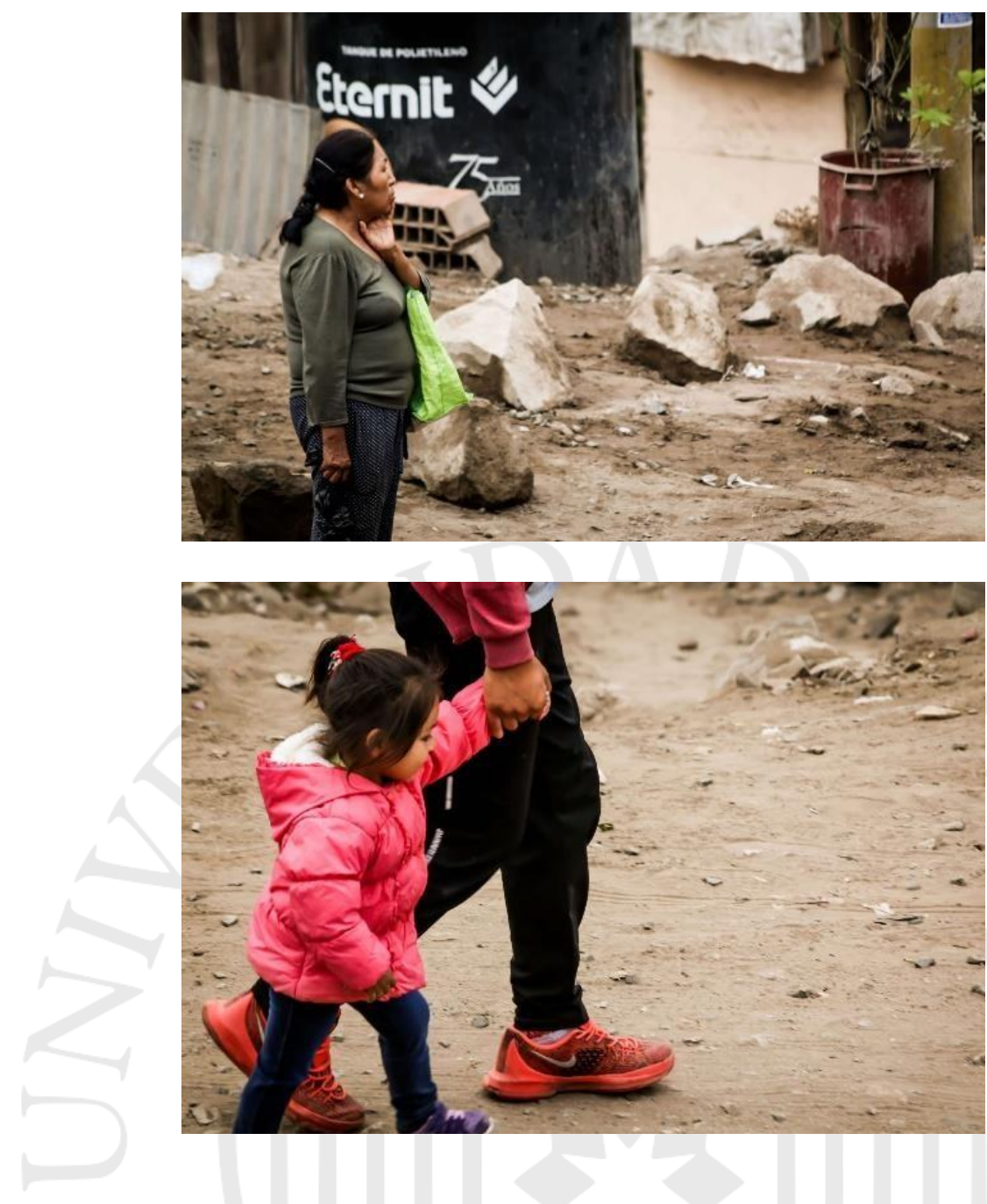

\subsection{Material Complementario}

\subsubsection{Grabaciones}

Las grabaciones se iniciaron en octubre del 2016, cuando se realizó la primera entrevista con Oscar Leiva. El proceso fue lento y discontinuo pues hubo prioridad en la fotografía, sin embargo, se obtuvieron buenos resultados que aportaron enormemente en la creación del corto video documental. 


\subsubsection{Video Documental}

El video completo se puede encontrar en www.proyectonudo.wordpress.com

El objetivo del documental era narrar aquellos relatos que las fotografías contaban a través de las entrevistas y de una mirada más general del lugar. Se buscaba contextualizar, así como informar, en ciertas escenas, la situación que se vive en la capital del Perú.

Las entrevistas son puestas aleatoriamente respondiendo a preguntas específicas que se hicieron, en su mayoría, a todos los entrevistados, y es entre una pregunta y otra donde se narra poéticamente la historia de esas comunidades, con mensajes que buscan generar reflexión y diálogo en el espectador. Se utilizó el texto de Andrea Beteta, curadora de la exposición.

El contenido es el siguiente:

- Entrevistas a pobladores

- Vistas generales de la comunidad (paneos del paisaje y tomas estáticas a detalles)

- Tomas del drone en el límite de Casuarinas y Pamplona

\subsubsection{Banda Sonora}

Los tracks completos se pueden encontrar en el blog en línea.

Durante la edición del video se optó por tener una banda sonora específica que mezclara los sonidos de las comunidades con música que se suele escuchar allí como chicha, cumbia o salsa. En un inicio, se pensó en el video como algo experimental conformado de imágenes yuxtapuestas que irían acompañadas de la música. Sin embargo, esa idea quedó descartada ya que iban a ser necesarias algunas 
pantallas y audífonos para tener una mejor experiencia, y en tal caso, el lugar elegido no contaba con esas instalaciones.

Fue con la colaboración de Global Studios que se lograron crear 3 tracks, secuencias musicales, que acompañarían el video documental. Esta música también sonó en la exposición, como parte de la experiencia. El resultado final fueron algunos sonidos ambientales, como las pisadas en la tierra, los perros ladrando, gente martillando y el señor que vende frutas haciendo promociones, y una cumbia tranquila creada desde cero.

\subsection{Instalación}

La referencia principal para elegir que no solo sea una exposición sino también una instalación, fue el proyecto de TECHO - USA que se hizo en el 2015, donde se tomaba un departamento en Manhattan y se ambientaba en el interior como una vivienda de bajos recursos. El departamento se ponía en alquiler como lujoso y bien ubicado, pero causaba un gran impacto cuando las personas llegaban al lugar y veían otra realidad a la que esperaban.

La intención de la instalación fue contextualizar, físicamente, el espacio. Es decir, crear un ambiente que permita que los visitantes experimenten, de forma mínima, la situación en la que viven allá los vecinos de las comunidades. Se buscó generar incomodidad, crear barreras físicas a modo de conceptualizar el muro en sí y lo que decían el resto de fotografías.

Las tomas de montaje de instalación de cuadros y objetos están en www.proyectonudo.wordpress.com 


\subsection{Difusión en medios}

\subsubsection{Impreso}

Las tarjetas de invitación a la inauguración fueron en papel grueso mate de un tamaño de $11 \mathrm{~cm}$ por $11 \mathrm{~cm}$ con una foto en la portada, el nombre del proyecto y atrás, información del lugar, hora y los nombres de los auspiciadores: Global Studios y Prints and Photo Solutions SAC

\section{Parte de adelante}

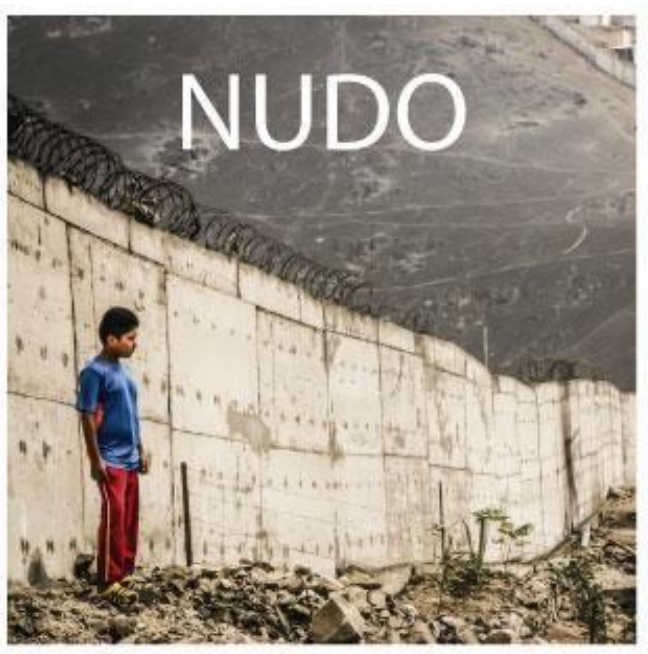

\section{Parte de atrás}

PROYECTOOE ESPECIALIZACION DEANDREACHIRINOS

INAUGURACIÓN

24.02.17 - 20:00 hrs

HASTA EL 16 DE MARZO

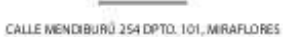

ESPACIO

$L \wedge S \wedge L \wedge$

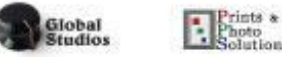

\subsubsection{Redes sociales}

En el caso de las redes sociales, se creó un evento en Facebook, donde se expone el texto curatorial y la invitación, adaptada a la portada del evento con los datos necesarios para que los espectadores sepan cuándo, dónde y a qué hora se está dando la exposición. 
Estas son las portadas que se han usado:

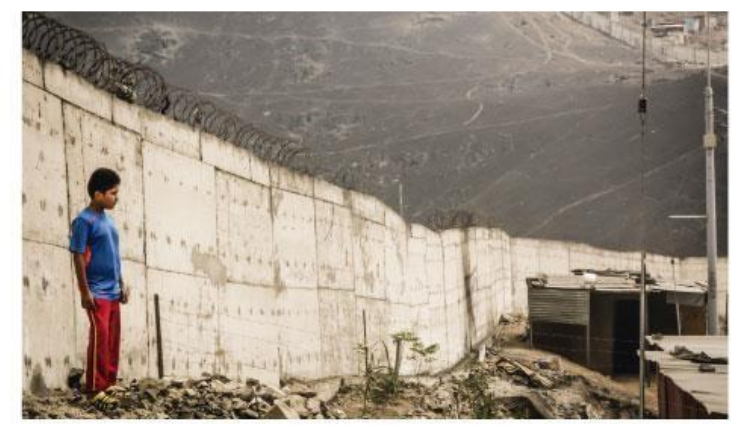

\section{NUDO}

PROYECTO DE ESPECIALIZACIÓN ENDREA CHIRINOS

INAUGURACIÓN

24.02.17 - 20:00 hrs

HASTA EL 16 DE MARZO
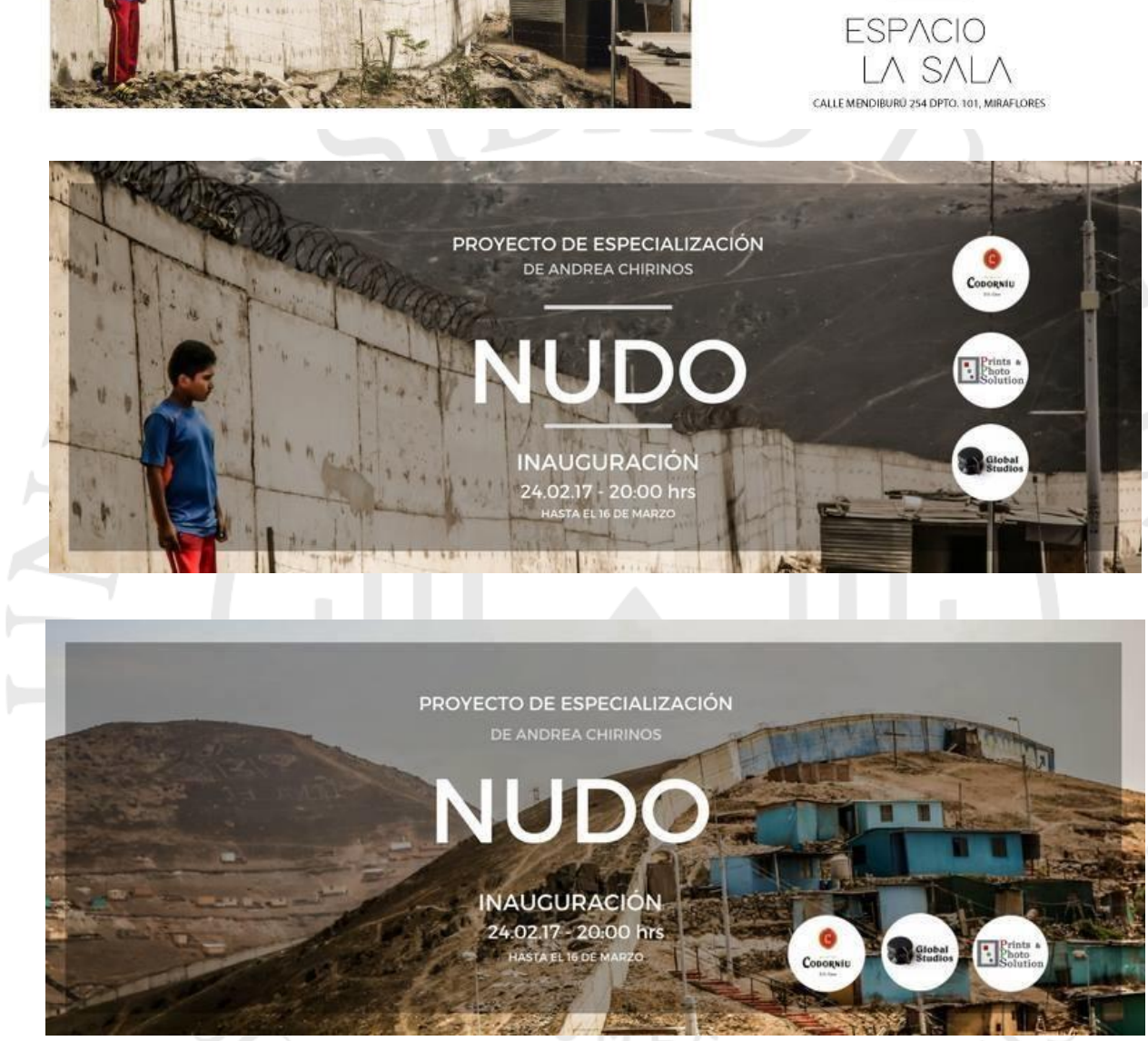

Link del evento: https://www.facebook.com/events/1354960701232286/ 


\subsubsection{Mailing y Medios Digitales}

Este afiche se envió en un Mailing a los voluntarios de la ONG TECHO para invitarlos a la exposición, así como a los medios digitales (prensa) para la redacción de las notas en distintos medios. Esta presentación, al contrario de las anteriores, tiene un extracto del texto curatorial que fue redactado por Andrea Beteta.

iHola! 3

Sabemos que TECHO es una cantera de grandes voluntarios/as, personajes, lideres/as, personas comprometdas con el desarrollo social en general.

Por eso, creemos importante invitarlos/as a "NUDO", instalación artística realizada por Andrea Chirinos, techera de corazón, que ofrece una reflexión sobre el muro que separa Casuarinas de Pamplona, ubicado muy cerca a la zona donde trabajamos.

La instalación corre hasta el 16 de marzo en Espacio La Sala (Calle Mendiburu 254 Dpto 101) yel ingreso es libre. Pueden revisar más info acá: hitpp://www.enlima.pelagenda-culural/exposicion/nudo

iNo falten!

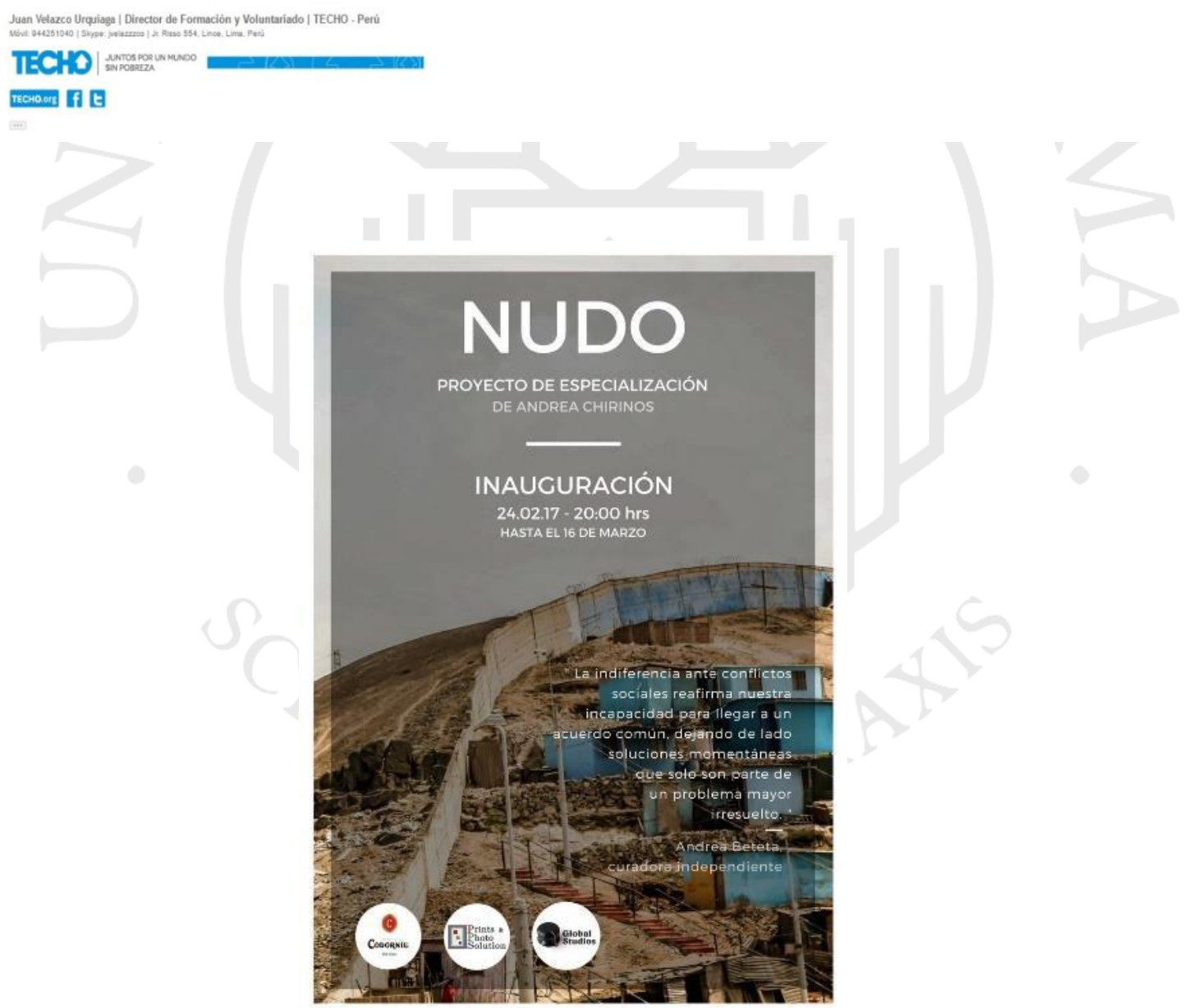




\section{SUSTENTACIÓN}

\subsection{Tratamiento fotográfico general}

\subsubsection{Técnica fotográfica}
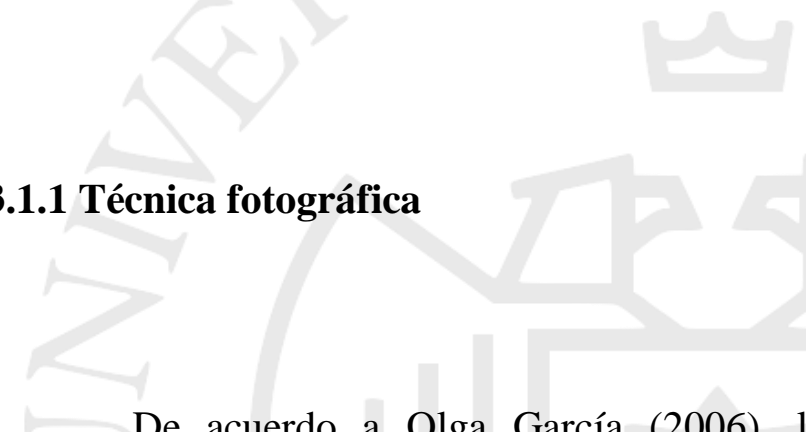

De acuerdo a Olga García (2006), la fotografía periodística es un área necesaria para la comunicación social donde se combina el talento y sensibilidad del reportero para poder narrar una historia a través de la imagen. Es en ese punto de partida donde el proyecto entró en conflicto pues la historia que se quería narrar no era clara. Fue durante las primeras visitas a las comunidades aledañas al muro donde los relatos se fueron formando y poco a poco la historia se consolidó gracias al grupo de personas de una misma condición social que participaron directa o indirectamente en el proyecto.

Parafraseando a Luis Teixeira (1999), los registros son producidos con una finalidad documental y representarán siempre un medio de información y conocimiento. Sin embargo, el proyecto no debía ser solo una fuente de información, se buscaba llegar más allá, contar una historia y generar reflexión. La estética de la imagen también era importante. Se debía trabajar en el espacio y componer fotográficamente para que la colección tuviera una "estética específica" por así decirlo. Una de las bases del fotoperiodismo es que al narrar una historia se deben combinar dos factores importantes: la ética y la estética. Ética, en cuanto a no deformar la verdad de un hecho, 
pues como menciona Teixeira, la foto debe aparecer como el testimonio fidedigno y transparente del acontecimiento. Y estética, en cuanto a obtener la composición correcta en la imagen, no olvidarse de los colores, las sombras y luces, y así jugar con la imagen sin perder la fuerza que necesita el texto tácito que en ella se encuentra.

Por otro lado, Enrique Villaseñor (2005), menciona que el fotoperiodismo contiene ciertas categorías que funcionan como punto de partida para lo que significa la imagen realmente. Primero está la analogía, donde se encuentra un significado pre existente para otorgarle a cierta imagen, en este proyecto, por ejemplo, se trabajó con líneas con el propósito de otorgarle el significado de límite, trazo y separación y así sustentar el concepto de "nudo" que tiene la exposición. También está la semejanza que permite establecer relación entre elementos distintivos, lo que permitió pasar de un retrato a una foto paisajística en base a la relación significativa que podía encontrar en la imagen. Hubo mucha relación entre las líneas y dónde estaba peso de la imagen, así como las sombras, creando un contraste marcado que resalta el estilo en la colección y busca agudizar el mensaje.

Finalmente, José Cuevas (2014), menciona el tratamiento fotográfico y específico que se le hace a la pobreza vista como conflicto social, donde el enfrentamiento dialéctico que se produce en lo social y económico entre estos grupos se refleja asimismo en la representación que se lleva a cabo de la pobreza: desde la idealización, ocultamiento y desvirtualización de la misma hasta la postura crítica y comprometida que intenta devolver esa realidad a la sociedad.

El Proyecto Nudo ha sido una combinación de muchos aprendizajes obtenidos en el camino. Desde empezar con fotografías únicamente de paisaje, hasta probar retratos y detalles, crear formas, contar una historia. Si bien el muro empezó como protagonista, fueron las personas y su forma de habitar lo que terminó sobresaliendo. 


\subsubsection{Técnica en Edición}

Desde un inicio, se optó por darle a la imagen un aspecto contrastado, cálido y hace énfasis en las sombras y luces. Se halló una estética específica a través del uso de HDR que permitió uniformizar la colección y a la vez crear una sensación de fantasía en la propia imagen, sin embargo, algunas fotografías lo tienen más remarcado que otras.

Javier Trabadela menciona que:

"Los fotógrafos pierden precisión y exactitud en la toma de las imágenes originales, relegándolas a procesos ulteriores de ajuste y retoque. (p.9)” (2005)

El revelado es un proceso aditivo que incluso puede no ser necesario, sin embargo, el aspecto terroso del espacio invitó a probar algunos retoques fotográficos que explotaran esa propiedad. Lo que hacía falta era darle un poco de color puesto que, aunque muchas casas si tenían distintos tonos, se veían invadidas por la tierra a su alrededor. Como primera opción se optó por la calidez, lo que incrementó el aspecto terroso. Luego se aplicó la desaturación y un poco de viñeta como modo de darle un marco a la imagen y crear un centro.

Esa primera edición no iba a funcionar dado que le daba a la imagen un aspecto devastador e incómodo donde la imagen recurriría a un dramatismo de una situación no novedosa: la pobreza en Lima. Sin embargo, no se descartó la posibilidad de elegir algunas fotos de esa primera selección y se eligieron algunas que complementarían la historia a través de ese aspecto desaturado. En esta primera selección también se utilizó el blanco y negro, a modo de contrastar las sobras y luces que encontraba en el paisaje. Se consideró hacer uso del blanco y negro para toda la muestra, sin embargo, era necesario tener un color que caracterizara el espacio sin hacer que todo se vea como tierra. 
Nieves Limón dice que:

"La fotografía puede construir imágenes que no tienen por qué ser un espejo de lo acontecido sin que por ello dejen de parecerse a las escenas sucedidas. (p.8)" (2012)

Fontcouberta menciona que:

"Cada fotografía no es más que una falsificación de principio a fin; una fotografía impersonal y no manipulada es prácticamente imposible. (p.1) (2011)

Se hicieron algunos recortes en las fotografías originales para componer la imagen y que sirvieron para reforzar las líneas que se encontraban en el paisaje. En una segunda selección, el foco estuvo en los retratos, la piel, la vestimenta y los objetos que utilizaban. Se trabajaron las sobras, exposición de acuerdo a la necesidad de la fotografía. No hubo ningún retoque extra como se alisamiento o borrado de manchas. Si se manipuló la luminancia para eliminar el ruido de algunas fotografías.

En cuanto a las fotos de paisaje y detalle, se resaltó el color de las paredes, escaleras y diversos objetos. No se optó por la saturación, sino que mantuvo el mismo estilo que los retratos, pues no se buscaba tener muchas tonalidades o temperaturas dentro de la colección, la variación se encontraría en el paso del color a el uso del blanco y negro. Hubo prioridad, como ya se ha mencionado, en el contraste, a modo de profundizar en la cruda realidad en la que vive un alto porcentaje de los habitantes de Lima.

El blanco y negro sirvió en algunas fotografías minimalistas como a zapatillas colgadas o los fierros de una casa a medio construir. También se utilizó en algunas fotos de paisaje y retratos, buscando resaltar sobras y luces para crear un camino específico en la mirada del espectador. En conclusión, la técnica que primó en mis fotografías finales fue el contraste, el HDR y luminancia, así como el tono cálido y recorte con el fin de componer pensando en líneas, en muro y en la historia que estaba contando. 


\section{LOGROS Y RESULTADOS}

\subsection{Exposición/Instalación Fotográfica}

\subsubsection{Entrevista Radial}

El día jueves 23 de febrero del 2017, se realizó una entrevista radial en la radio Filarmónica 102.7, junto a André Pereyra, dueño de la galería, y Andrea Beteta, la curadora de la exposición. La entrevista se realizó en el programa Meridiano, bajo la conducción de Carlos Fernández Loayza, y constó de preguntas dirigidas a un porqué la realización de la muestra, dónde nació el interés, cómo fluyó el trabajo conjunto a la curadora, entre otras preguntas puntuales con el propósito de generar interés en los oyentes y extender la invitación a las personas para que asistan a la inauguración de la muestra. 


\subsubsection{Nota de Prensa}

Las notas de prensa comenzaron a salir aproximadamente una semana antes de día de la inauguración. Estos son los tres links de las notas de prensa que fueron publicadas en la web:

http://www.limagris.com/nudo-exposicion-individual-andrea-chirinos/

http://dosis.pe/artista-andrea-chirinos-presenta-exposicion-individual-nudo/

http://www.enlima.pe/agenda-cultural/exposicion/nudo

Un anuncio en la sección de Grados y Posgrados del dominical del Comercio (a la izquierda) y un artículo en Expreso (a la derecha).

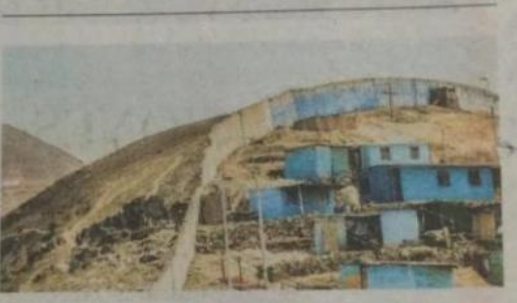

Exposición

NuDo, muestraindividualdelafotógrafa

AndreaChirinosque exploralas realidadesque segmentay excluyeelmuroentrePamplonay Las Casuarinas, seencuentraenelEspacio LaSala (calleMendiburu254,dpto.101, Miraflores) hastael 16 demarzo. Horario:demartesa domingo, de 10:00 a20:00. Ingresolibre.
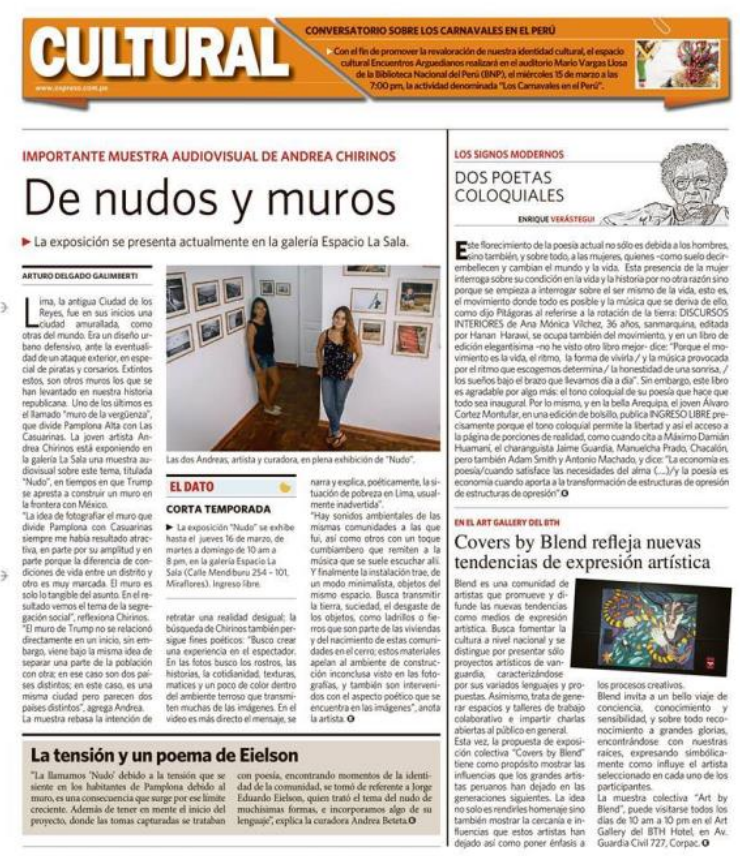


\subsubsection{Inauguración}

Las fotografías presentadas en la exposición/instalación se encuentran en www.proyectonudo.wordpress.com y en el perfil de Instagram del proyecto. (@proyectonudo)

La inauguración de la exposición se dio a las 8:00pm el día viernes 24 del 2017 y contó con la asistencia de alrededor de 60 personas. Se inició con una pequeña introducción de André Pereyra, seguido de las palabras de Andrea Beteta y finalmente las de Andrea Chirinos, para dar paso a la muestra.

Antonio Rengifo Balareza, antropólogo de la Universidad San Marcos, dio un pequeño discurso sobre la importancia de este tipo de proyectos. Se extendió la propuesta de expandir el proyecto por el jefe de artes visuales del ICPNA, Charles Miro-Quesada.
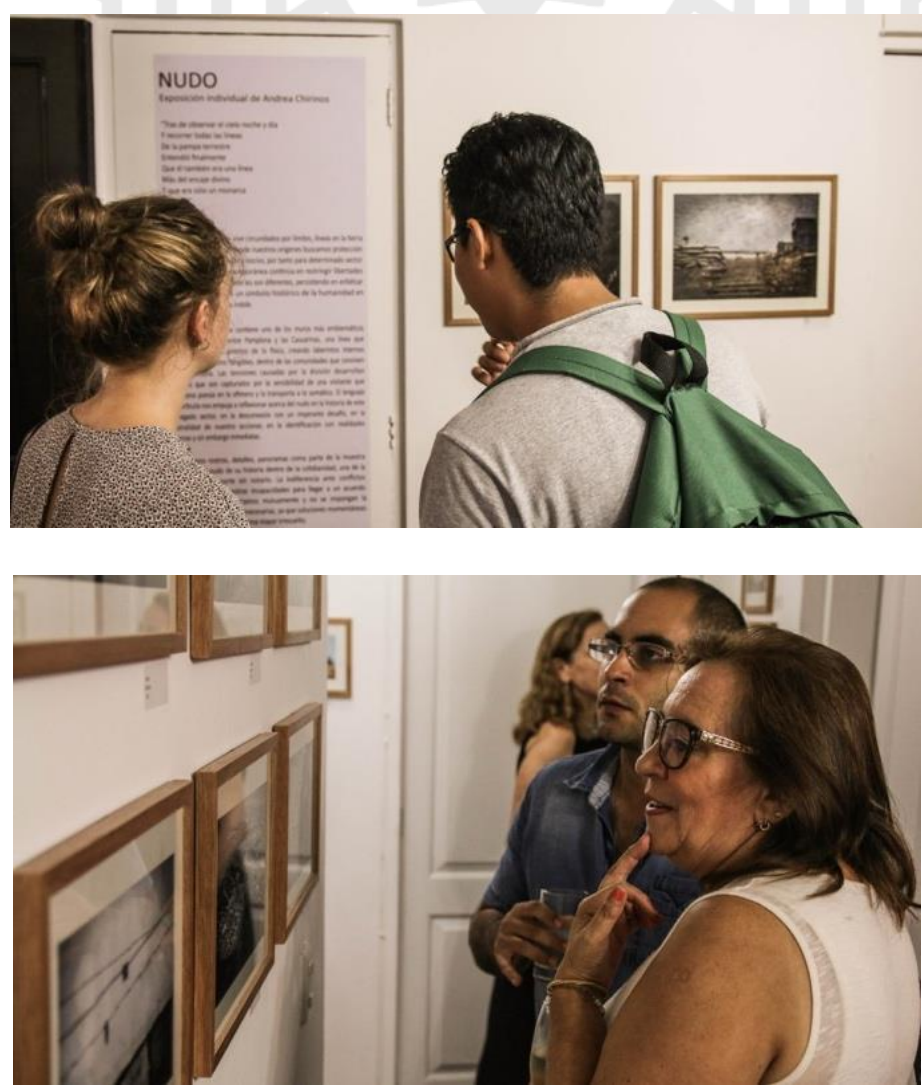


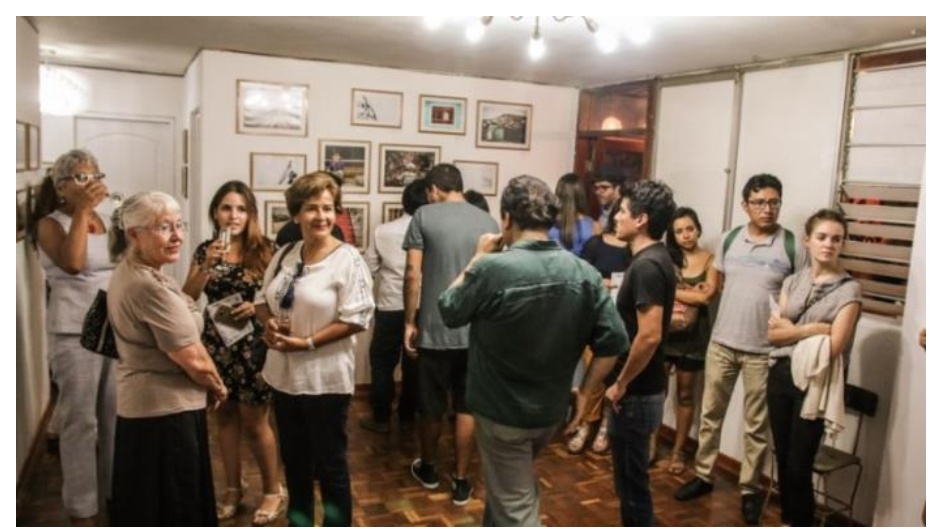

\subsubsection{Conversatorio en Espacio La Sala}

El 16 de marzo del 2017 se realizó un conversatorio en Espacio La Sala y contó con la asistencia de 30 personas aproximadamente. Los invitados fueron:

\section{- Antonio Rengifo}

Licenciado en sociología. Enseñó en la Universidad Nacional de Ingeniería y en Universidad Ricardo Palma, en las facultades de Arquitectura y Urbanismo.

\section{- Luz Ramos}

Antigua dirigente de la comunidad de Cerro Verde, Pamplona Alta. Mujer, amiga, madre, moradora y lidereza.

\section{- Juan Velazco}

Politólogo. Director de formación y voluntariado en la ONG Techo- Perú

\section{- Alessandra Nakano}

Practicante de psicología de Epicentro. Integrante del colectivo Taripay Pacha. Interesada en temas relacionados a la sexualidad y poblaciones en estado de vulnerabilidad.

\section{- Carlos Chávez}

Realizador audiovisual. Integrante del colectivo Taripay Pacha. 
Durante este espacio de diálogo surgieron diversas posturas alrededor del muro, así como puntos fuertes centrados en qué hacer al respecto y cuál es la solución que mejor beneficiaría a ambas partes.

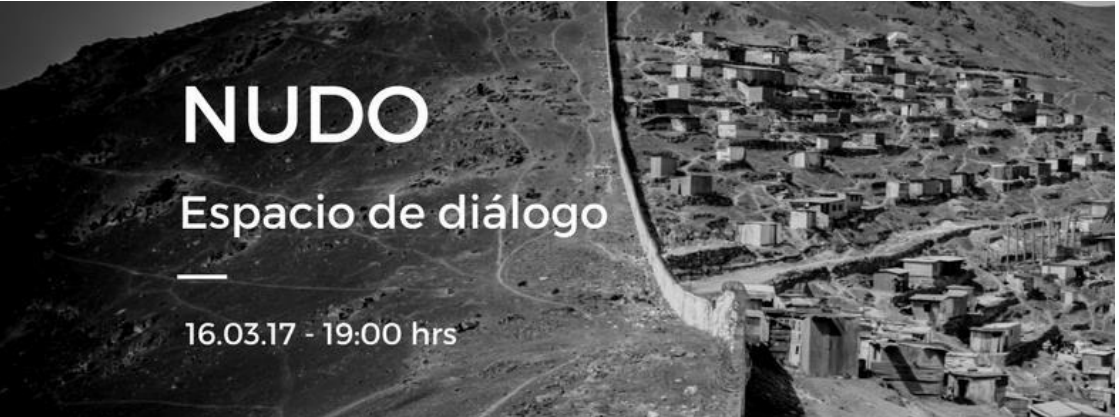

\subsubsection{Presentación en la Universidad Nacional de Ingeniería}

El 5 de abril del 2017 el proyecto se expuso a los alumnos del taller de diseño arquitectónico IV en la Facultad de Arquitectura y Artes de la Universidad Nacional de Ingeniería gracias a la invitación del arquitecto y profesor Jorge Záldivar, quien estuvo presente en el conversatorio de cierre de la exposición/instalación Nudo.

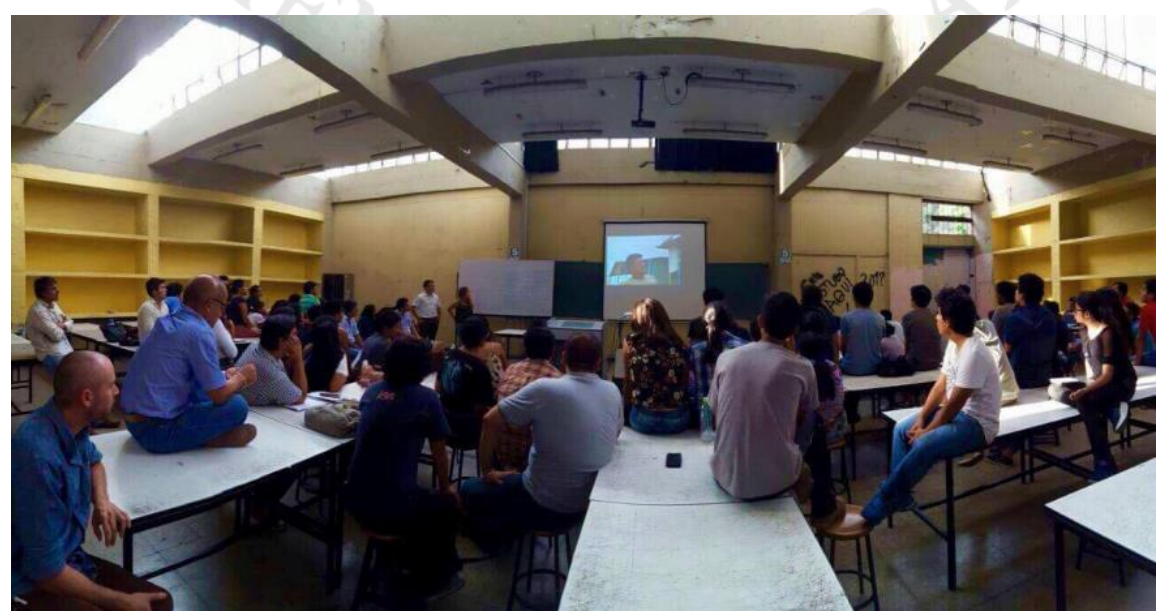




\subsubsection{Participación en la Obra Teatral "Muros"}

Parte del video documental se utilizó en la obra "Muros" que se presentó el 21 de junio del 2019 en el Teatro de la Universidad del Pacífico y fue dirigida por Paloma Carpio, quién se puso en contacto para poder hacer uso de ese material.

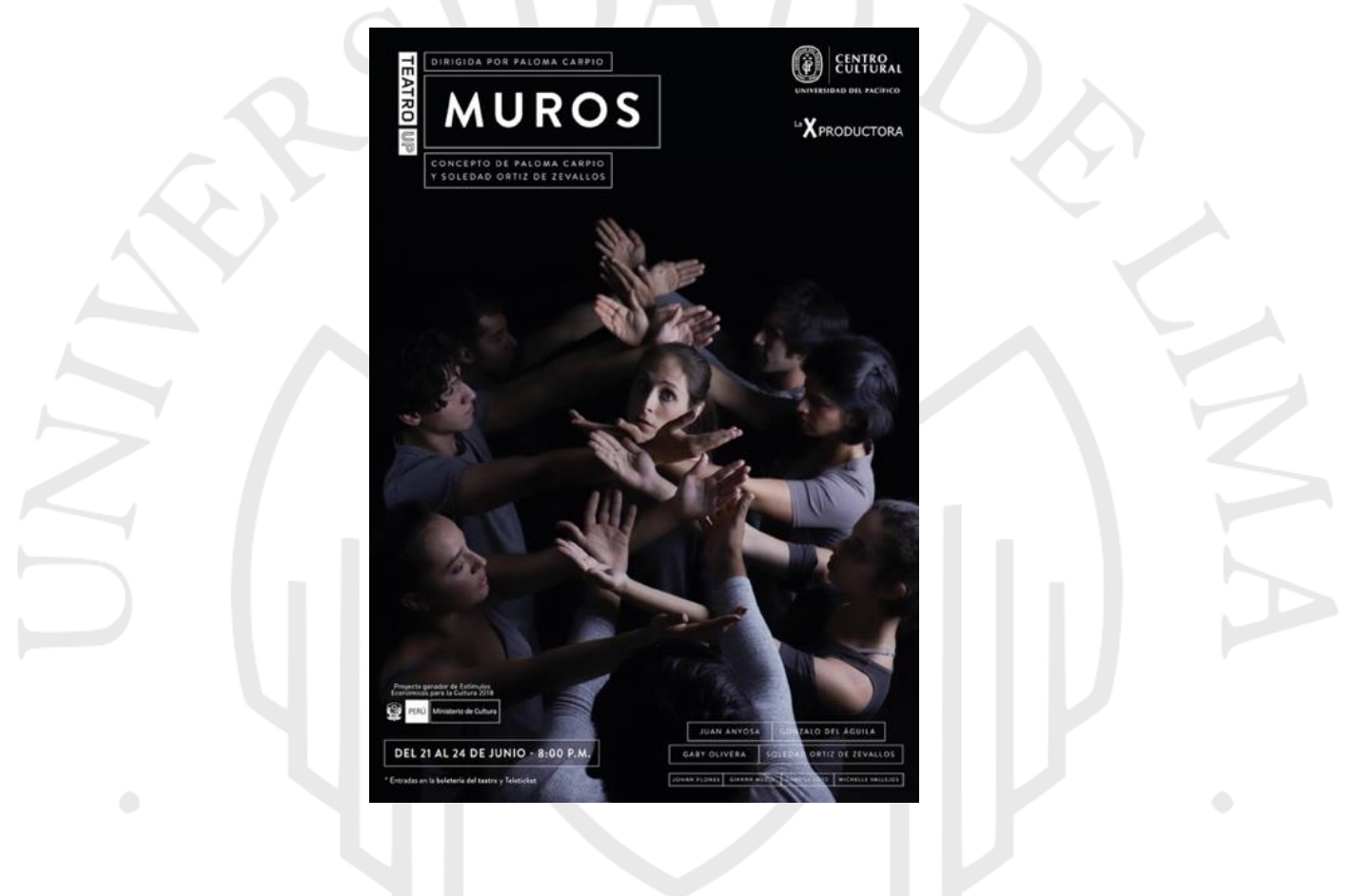

\subsubsection{Exposición Fotográfica en la comunidad El Trébol}

El sábado 11 de enero del 2020 se realizó una segunda exposición de las principales fotografías de la colección en el salón comunal de la comunidad El Trébol a modo de cerrar el proyecto y mostrar las fotografías en el lugar donde fueron tomadas. En diciembre del 2019 se retomó el contacto con Luis Flores, actual dirigente de la comunidad, y se propuso hacer la exposición en el salón comunal. La idea coincidió con el 20 aniversario de la comunidad que tuvo como fecha el 6 de enero, pero que se iba a celebrar el 11 de ese mes. 
Se acordó entonces en presentar las fotografías a modo de celebrar lo mucho que han avanzado desde sus inicios. El dirigente propuso presentar fotografías que tenían de las primeras faenas y el trabajo en comunidad, y también se pensó en tener fotografías más recientes de los espacios más significativos del lugar, como la loza deportiva, el salón comunal, la biblioteca y el parque de juegos. Esas nuevas fotografías se realizaron a fines de diciembre del 2019, sin embargo, las fotografías de archivo no se pudieron encontrar.

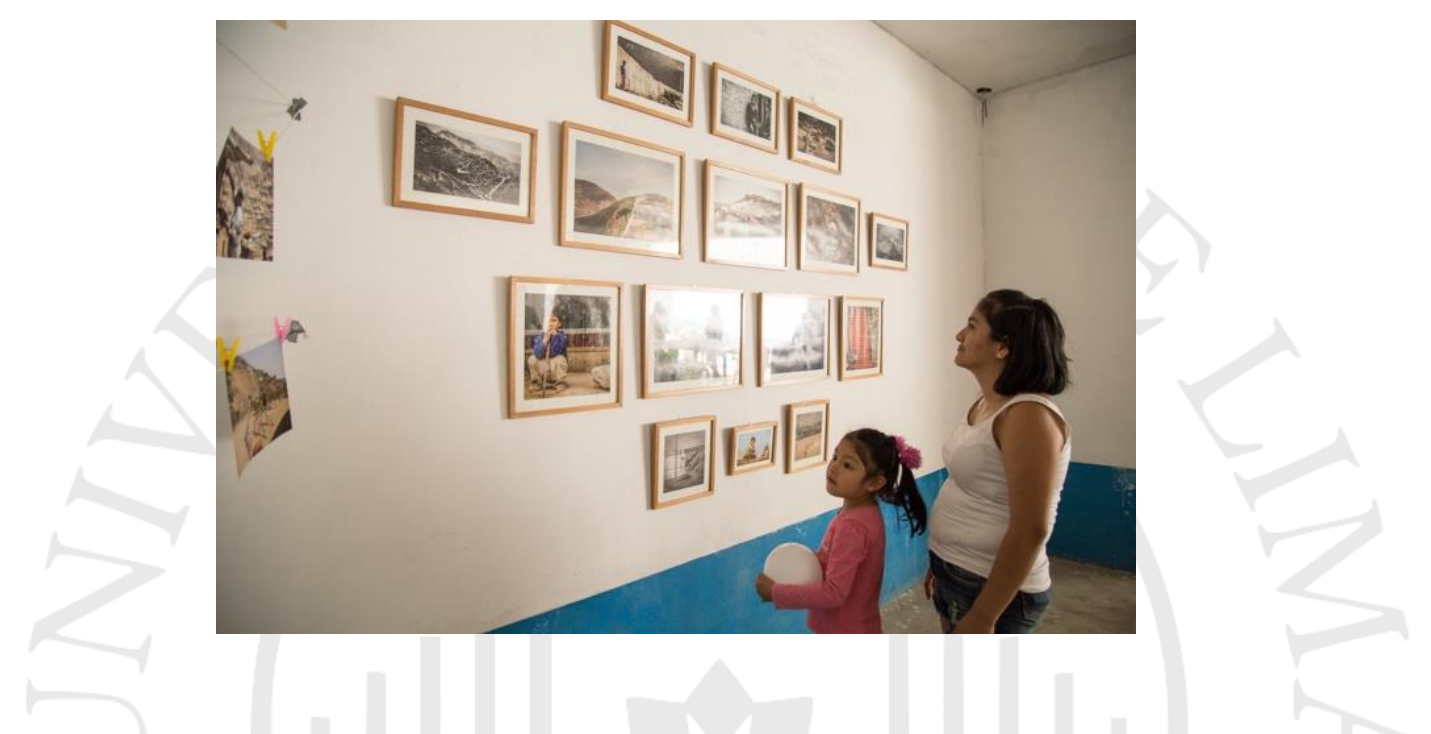

Sumándose a la celebración el equipo de comunidad de TECHO organizó una kermés ese día desde temprano donde hubo una tómbola, bingo y venta de ropa, todo con el propósito de juntar dinero para utilizarlo en la construcción de escaleras, señalización entre otras necesidades.

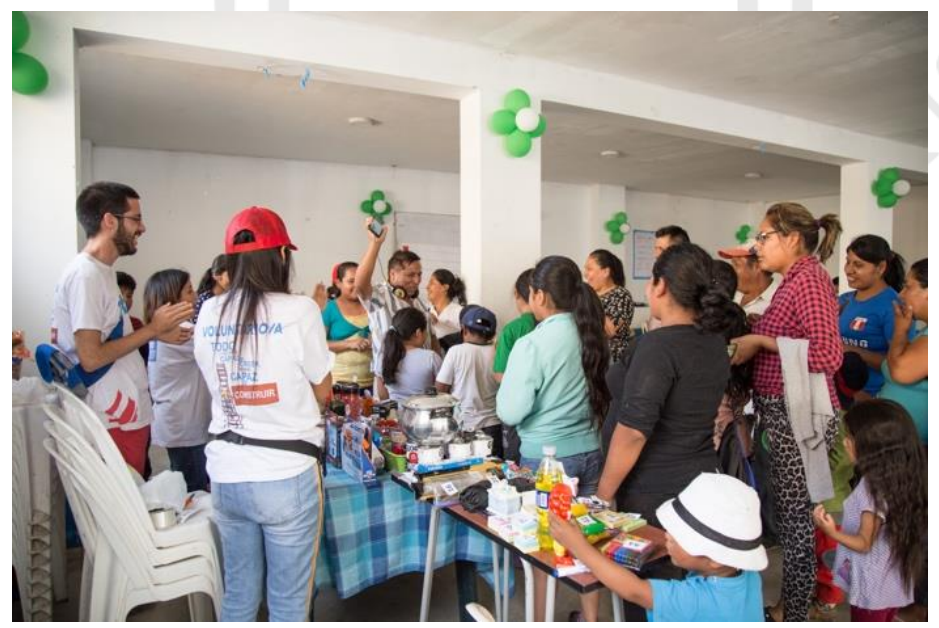


Durante la exposición, las personas se acercaban de forma tímida para buscarse en las fotografías. Reconocían los lugares y se identificaban con el lugar. Hacían mención de cómo en sus inicios no había nada y se sentían felices de ver cómo habían mejorado. Aunque la muestra contaba con fotografías de comunidades aledañas, comprendían que el espacio era el mismo y que al final todos buscaban crecer. Algunas fotografías del muro también se expusieron y lo reconocían como "el muro de la vergüenza".

Una señora opinó que el muro estaba bien construido pues era una forma de protegerse de los que podían pasar a robar del otro lado, y viceversa. Ella consideraba al muro como un símbolo de protección y seguridad, incluso recalcó que, si pudiera poner muros entre comunidades, lo haría. Un señor mencionó que es bueno retratar cuando se comienza con el terreno, cuando se va progresando, pero que aún falta mucho por mejorar. También se opinó que las fotografías ayudaban a difundir y hacer un pedido de ayuda y apoyo por parte del estado y el resto de organizaciones que quisieran contribuir al crecimiento.

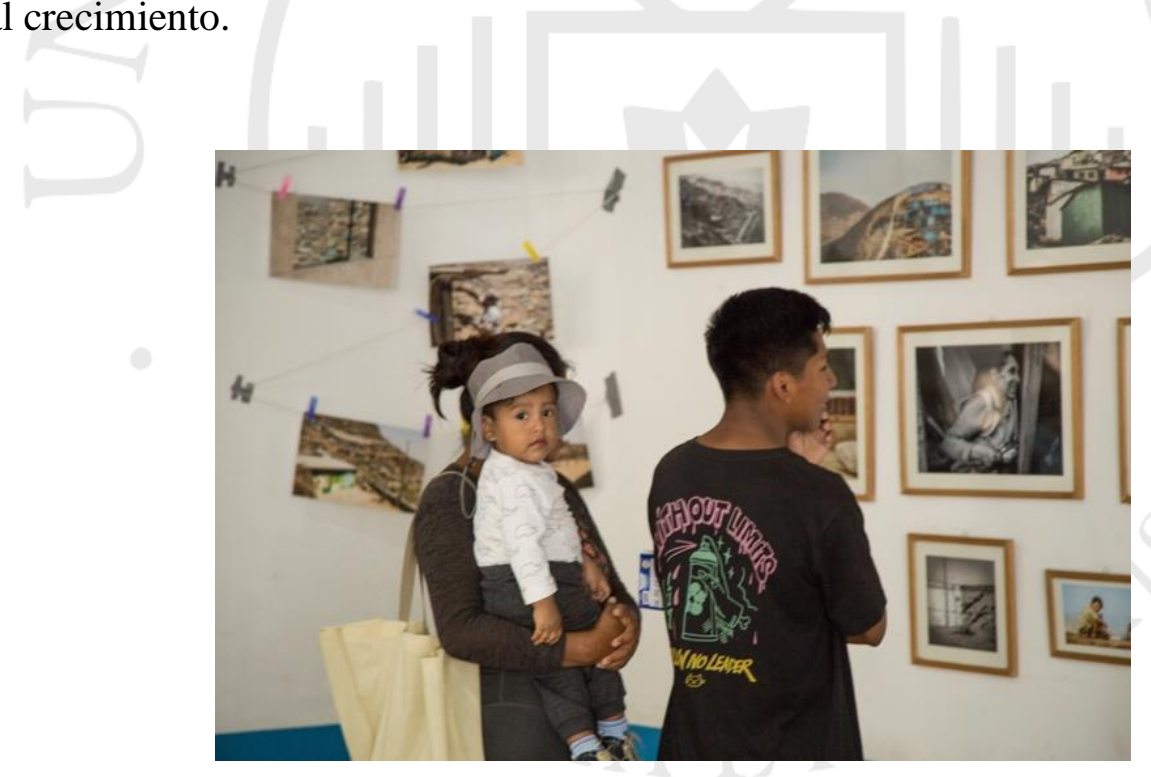




\subsection{Méritos}

\subsubsection{Cualitativos}

El mérito cualitativo principal fue ampliar los conocimientos sobre la situación que se vive en Pamplona, específicamente, en las comunidades que colindan con el muro. Se tuvo la oportunidad de llegar más allá a lo que ya se sabía y conocía, y obtener no solo un resultado informativo, sino también artístico y reflexivo. Otro mérito fue lograr llevar a cabo una exposición de calidad, fruto del esfuerzo de muchos meses. Se fomentó el diálogo y se creó un espacio abierto al debate.

\subsubsection{Cuantitativos}

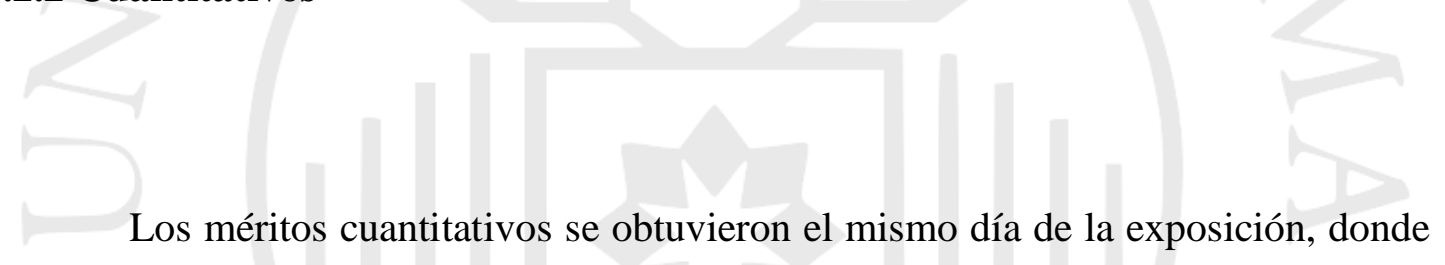
la muestra tuvo gran acogida y aceptación por parte del público. También se apreció en el número de personas que recibió el conversatorio de cierre de la exposición

\subsection{Dificultades}

Una de las principales dificultades fue el ingreso a un espacio que es conocido por el alto índice de inseguridad y de robo. Una igual de importante es el reto de crear una conexión a través de la fotografía para dar a conocer la realidad alterna que vive el $21,8 \%$ de la población limeña. Esta dificultad no solo se tuvo mediante la fotografía, sino también a través del discurso narrado en el video, donde se quiso exponer la realidad y dejar en claro los problemas sociales que se pasan por alto, que no son recientes y que se siguen perpetuando mediante obstáculos físicos como la existencia del muro. 
La dificultad de transmitir ese tipo de mensaje, sin llegar a la pregunta que se hizo el día de la exposición: “¿Cuál es la solución si no es a través de un muro?”, es mucho más compleja de lo que parece, pues un texto siempre tiene una postura, que intentará inducir al lector a pensar de cierta manera. Aquello es algo inevitable. 


\section{LECCIONES APRENDIDAS}

Todo proyecto tiene su propio proceso y ritmo creativo, el de este empezó a variar desde el momento que se optó por el tema, desde la elección de la comunidad más concurrida hasta la presentación de las fotografías en el aniversario de esta. El enfoque del proyecto era clave para la realización de este, y si bien en un inicio fue pensado únicamente en la etnicidad de la naturaleza del tema, luego se adquirió también un enfoque artístico, dando como resultado un híbrido que combina poemas de Eielson son la cruda realidad de cada fotografía.

\subsection{Aprendizaje}

\subsubsection{Profesional}

Uno de los aprendizajes profesionales que se obtuvo durante el proceso del proyecto fue el nivel de organización que se debía tener para hacer que el proyecto sea viable. Desde la primera vez que se llegó a la comunidad hasta la exposición realizada ahí mismo, era evidente la necesidad de armar un cronograma de actividades necesarias para que el proyecto tuviera coherencia y contara una historia a través de la fotografía, principalmente, y también del video. 
Además de contar con un cronograma de actividades al iniciar el proyecto, también es importante hacer una búsqueda intensiva del trabajo previo realizado en el lugar a trabajar. Esto permite tener una idea clara de lo que ya se ha hecho para encontrar otro punto de vista del cual narrar. Este proyecto, por ejemplo, tenía y siempre ha tenido, diversas visitas al famoso "muro de la vergüenza" y lo que se ha solido hacer es tomarlo del punto de pamplona y cómo este representa lo dividida que está Lima. Se buscó contar un poco más, ampliar el panorama y no solo contar la historia del muro en sí, sino hablar de la gente y las condiciones de vida paralelas al muro. Un proyecto a futuro, podría incluso alejarse de aquella división y centrarse más en las familias, las costumbres, el folklore, etcétera. Hacer un estudio más etnográfico, por así decirlo.

Cada decisión tomada fue definiendo el producto final, y no fue hasta 3 años después, cuando dichas fotografías más otras tomadas en el presente, fueron expuestas para el aniversario de 20 años de la comunidad el Trebol, con el agradecimiento y el consentimiento de la Junta Directiva. Es clave no cerrarse en ideas propias, tomar opiniones ajenas y abrirse siempre a nuevas formas de contar historias a través de la fotografía.

\subsubsection{Personal}

Como mayor aprendizaje personal, fue el trabajar de cerca la realidad que se vive al costado del muro. El trabajo en comunidades específicas, y principalmente la del Trébol, hace entablar un lazo con algunas personas que se cruzaron en el camino del proyecto y que, después de largas conversaciones, llevan a cuestionar si uno es suficientemente agradecido con lo que le ha tocado vivir y también, si es que se está haciendo algo para apoyar al prójimo. 


\subsection{Recomendaciones}

Es importante, antes de empezar a realizar un proyecto como este, armar un cronograma de trabajo que incluya tanto: visitas a la comunidad, preguntas preparadas para las entrevistas a realizar, registro fotográfico de cada visita detallando la fecha y el lugar visitado, y notas generales después de cada visita para tener una mirada amplia de lo que se va obteniendo para el proyecto.

Asimismo, es un trabajo que requiere bastante paciencia y tiempo dado que, para tener mejores resultados, se necesita tener una relación estrecha con la comunidad a tratar, de lo contrario, resultará más difícil obtener entrevistas y retratos provechosos.

A propósito de la relación con la comunidad, es recomendable registrar no solo las entrevistas grabadas, sino cualquier tipo de información que las personas estén dispuestas a ofrecer. El ingreso al lugar elegido debe ser de la manera más transparente posible, dejando claro los objetivos del proyecto para poder contar con la ayuda de los habitantes. Asimismo, debe haber un total consentimiento del uso de las fotografías y testimonios por parte de los involucrados.

Las visitas a la comunidad, o comunidades a trabajar, deben ser constantes y alrededor de 2 a 3 horas. La idea no es solo presentarse a fotografiar, grabar o entrevistar y tomar el bus de vuelta, sino más bien, lo importante es compartir con los habitantes, tener largas charlas, asistir a eventos del propio asentamiento. Es ahí donde la relación con ellos mejora y se logra ese lazo estrecho de complicidad del que tanto se ha hablado, es ahí donde se logra tener una mirada más clara de lo que es vivir en esas condiciones. 


\section{REFERENCIAS}

Arias, M. S. (2011). Grupos Sociales diferentes en aislamiento voluntario sobre la producción de nuevas formas de segregación socio espacial entre los distritos de Surco y San Juan de Miraflores. Obtenido de Universidad Nacional Mayor de San Marcos:

http://sisbib.unmsm.edu.pe/bibVirtualData/2011/delosantos_am/Tesis_Manuel_ De_los_Santos_final.pdf

Cortéz, S. (2008). Vergüenza de vivir donde vino: Ideas para una re-conceptualización de la segregación residencial socioeconómica. Recuperado el 2017, de AIBR, REVISTA DE ANTROPOLOGÍA IBEROAMERICANA: http://www.aibr.org/OJ/index.php/aibr/article/view/157

Soddu, P. (2006). Ceuta y Melilla: Gestión fronteriza, derechos humanos y seguridad. Recuperado el 2017, de Euro Arab Management School: https://www.iemed.org/anuari/2006/earticles/eSoddu.pdf

Naranjo, E. (2016). MÁS ALLÁ DEL MURO. LA CONDICIÓN URBANOTERRITORIAL DEL LÍMITE EN AMÉRICA LATINA. Recuperado el 2017, de Revista Diseño Urbano \& Paisaje - DU\&P: http://dup.ucentral.cl/dup_31/enrique_naranjo.pdf

San Filippo, L. (2012). Espacios en conflicto: un límite proyectado a través de un muro. Obtenido de http://www.rephip.unr.edu.ar/bitstream/handle/2133/5947/articulosan- filippo.pdf? sequence $=3$

Canfield, M. (1991). Lazos de color: Nudos de Jorge Eduardo Eielson. Recuperado el 2017, de Revista de Literatura Hispana:

http://digitalcommons.providence.edu/cgi/viewcontent.cgi?article=1547\&contex $\mathrm{t}=$ int $\mathrm{i}$

Fuera de Foco. (2017). Obtenido de http://fueradefoco.com.pe/cantagallo/

Goldstein, A. (2012). Vivir en la tierra. Obtenido de La Voz: http://www.lavoz.com.ar/espacio-de- marca/exposicion-de-andy-goldstein-enel-museo-de-fotografia-dionisi

Pacheco, O. (2012). Conductas Urbanas. Obtenido de IPCNA Cultural: http://cultural.icpna.edu.pe/conductas-urbanas-fotografia-testimonial-de-oscarpacheco/

Koudelka, J. (2015). Nacionalidad Incierta. Obtenido de Revista La Fundación: https://revistalafundacion.com/septiembre2015/exposicion/

RAE, R. A. (s.f.). Obtenido de https://dle.rae.es/nudo 
García, O. (2006). Un click entre la ética y el fotoperiodismo. Obtenido de http://www.biblioteca.org.ar/libros/152462.pdf

Texeira, L. (1999). Manipulación en el fotoperiodismo: ética o estética. Obtenido de Revista Latina de Comunicación Social: http://www.fotoperiodismo.org/fotografiadocumental.pdf

Villaseñor, E. (2005). Ética fotográfica. Ética y Fotoperiodismo. Obtenido de FOTOGRAFÍA PERIODISTÍCA Y DOCUMENTAL De autores, imágenes, procesos y ética fotográfica.:

http://www.fotoperiodismo.org/FORO/files/fotoperiodismo/source/html/textos/v illasenor $2 . \mathrm{htm}$

Cuevas, J. (2014). Imagen de la pobreza, pobreza de la imagen. Obtenido de http://roderic.uv.es/handle/10550/40355

Trabadela, J. (2005). Cambios en la Práctica Fotográfica como Consecuencia de la Digitalización en los procesos de Creación de la Imagen Fotográfica. Obtenido de http://www.razonypalabra.org.mx/anteriores/n45/jtrabadela.html

LUM. (2016). Exposición Permanente. Obtenido de LUM cultura: https://lum.cultura.pe/exposiciones/permanentes

Limón, N. (2012). POSPRODUCCIÓN DIGITAL: ÉTICA Y TEORÍA PARA UN NUEVO FOTOPERIODISMO. Obtenido de https://earchivo.uc3m.es/bitstream/handle/10016/16103/fotoperiodismo_limon_CISEP_ pp.pdf? sequence $=1 \&$ is Allowed $=\mathrm{y}$

Fontcouberta, J. (2011). Indiferencias fotográficas y ética de la imagen periodística. Obtenido de Editorial Gustavo Gili: https://ggili.com/indiferencias-fotograficasy-etica-de-la-imagen-periodistica-ebook.html

Garro, M. (2015). Éxodo Imposible. Obtenido de Museo de Arte Contemporáneo (MAC): http://www.maclima.pe/?exposiciones=exodo-imposible

Pigui, P. (2015). El polémico muro que separa a ricos y pobres en Lima. Obtenido de BBC Mundo:

http://www.bbc.com/mundo/noticias/2015/10/151019_peru_muro_barrio_pobre _ric o_lima_amv 


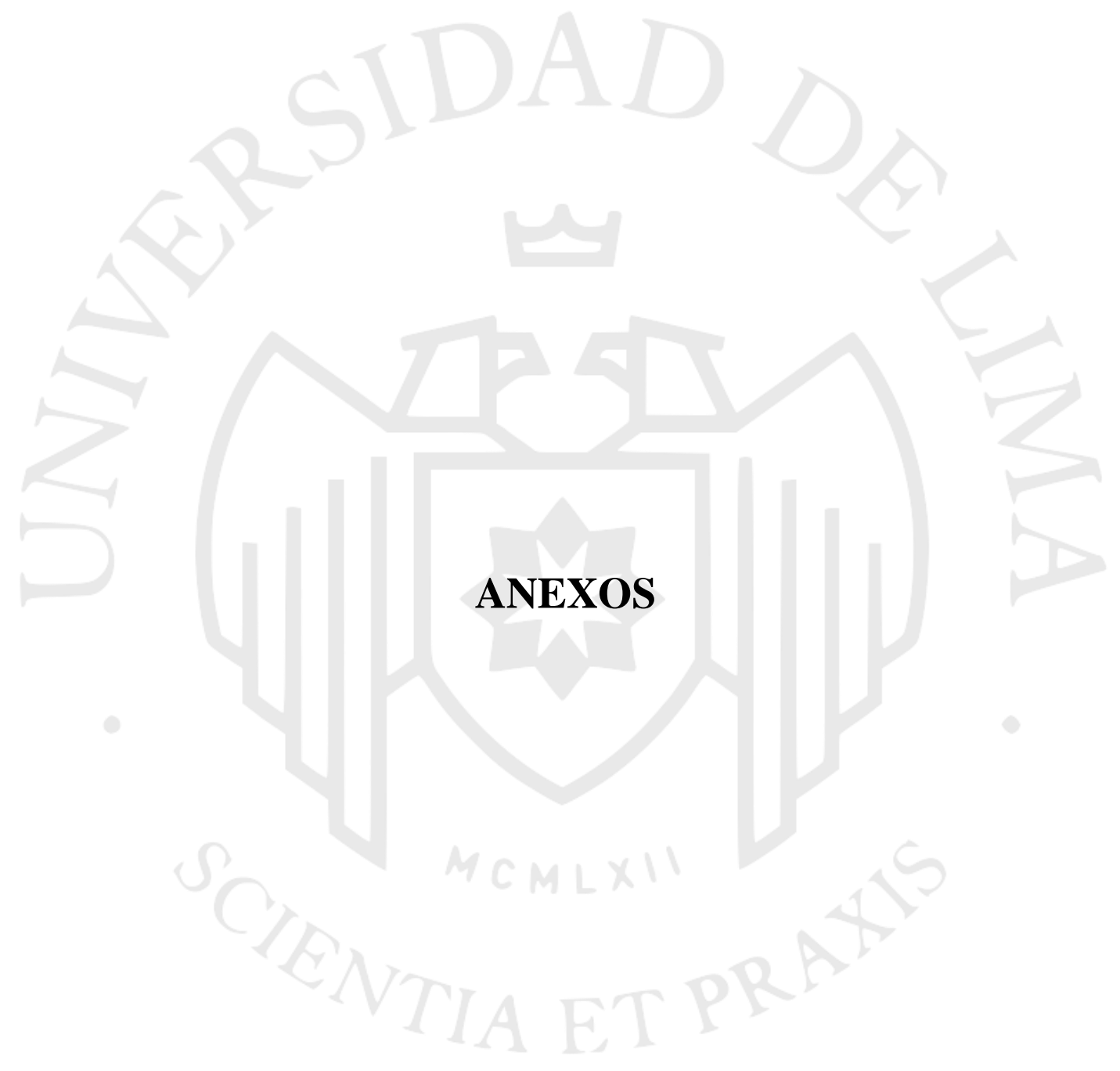




\section{ANEXO 1: Entrevistas a pobladores}




\section{Entrevista a Oscar Leiva}

\section{¿Cuéntame un poco del muro?}

Antes el paso era normal. Pero después ya le pusieron el muro. Hace poco nomás, no tiene ni 2 años el muro.

\section{He escuchado que una parte tiene como 15 años.}

Claro, pero esta parte no tiene más de 2 años. La parte de Casuarinas, esto es Casuarinas. Antes estaba así normal, cerro limpio, normal. Solamente había vigilancia policía, nomás. Pero ahora sí lo han cercado.

\section{¿Hasta dónde llega?}

Hasta la piedra, hasta la cruz. Y después voltea, pero con alambres así. Supuestamente decían que iba a salir una carretera por la Panamericana, hasta 12 de noviembre, por atrás, hacia Pamplona. De Pamplona a La Molina.

\section{¿Ya no habrá?}

Lo cancelaron pues, le pusieron el muro. Por eso le dicen el "Muro de la Vergüenza". ¿Entiendes? La vergüenza porque separan pues, separan los ricos y los pobres.

\section{¿Qué opinas al respecto?}

Así es pues, qué se va a hacer. Al final todos somos humanos. La diferencia es el dinero. Creo que, entre los ricos y los pobres, más felices son los pobres. El pobre vive en la pobreza, pero vive feliz. Si te das cuenta, este el único cono que se divide así. En otros lugares no está pasando esto. Es mejor que un cerro te divida, pero no un muro 


\section{¿El muro tiene alguna puerta?}

Había una entrada, pero ya la sellaron. Había antes una entrada que servía para cortar camino. Mucha gente la usaba porque trabajaba para adentro, entonces cruzaban por ahí, para llegar a Casuarinas. Si no tendrían que darse un vueltón. Bajar hasta pista nueva y por el colegio que hay por ahí. En la puerta que pusieron había vigilancia policial, y obvio, está bien, pero no debieron cerrarlo.

A veces, cuando hay paro, no hay carros para ir a trabajar, entonces, cruzaban por el cerro nomás. No sé por dónde salían, pero llegaban al otro lado, y ahora ya no se puede, ya.

\section{¿Qué actividades hacen para mejorar la comunidad?}

Hacemos faenas. Domingos a las 8 de la mañana puedes encontrar un montón de gente. Trabajan desde las 6:30 hasta las 10:00. El local comunal está allá, dónde está ese kiosquito blanco.

Esta loza de acá fue donada por una ONG. Vinieron de Estados Unidos y trabajaron una semana acá. Jóvenes vinieron y lo hicieron, con nosotros también. Éramos más de 200 personas haciendo eso.

\section{Bastante trabajo.}

Harta chamba. Hacíamos pasamanos haciendo eso. Cargábamos piedras, cementos, todos trabajábamos. Y el domingo hicimos la inauguración. Jugamos fútbol de hombres y mujeres. Ellos vinieron como tú, tomando fotos, hasta que nos preguntaron ¿Qué necesitan? Y después de año y medio, volvieron para construir la cancha.

Es gente pues, que no tienen nada que hacer con su plata y les pasan la voz que acá necesitan y vienen a hacer de todo. Muros de contención, y bienvenidos sean, lo que sea. Hay que ser directos, las cosas como son. Tampoco es ser sinvergüenzas. 


\section{Entrevista a Octavio Mendoza}

\section{Cuénteme, ¿Cómo hacen para conseguir agua?}

Es todo un proceso. Para tener agua hay que cumplir con ciertas normas. Este año están haciendo la habilitación de las vías de acceso. Si no están habilitadas las vías de acceso, no pueden venir.

Ahora tenemos un plazo de 14 meses, en cual tenemos que habilitar. Ahora ha entrado el estudio técnico, de repente los has visto por ahí. Están haciendo el levantamiento topográfico. Ya empezaron hace un mes o dos meses. 


\section{Entrevista a Gerardo Palacios}

¿Cuál es la situación con Casuarinas?

Casuarinas compra el terreno a Lima. Tenían que arborizar 5 hectáreas hacia este lado, tenías que hacer un área ecológica. Pero nunca lo hicieron. Entonces, esto se ha repartido el estado, y los de Casuarinas siguen apelando y apelando.

\section{¿Para qué apelan?}

Esta parte era de ellos, y se la ha repartido el estado. No todo, más o menos de aquí, para arriba.

\section{¿Y ellos cuándo hicieron el muro?}

Habrá sido en los 90's. Cuando nosotros hemos 1legado, eso ya estaba ahí. En la época del terrorismo pues, esta era una zona roja. Acá había senderistas. Se escondían acá pues.

Y en esa época, el muro se construyó para evitar que pasen.

Claro. En ese entonces las invasiones comenzaban. Pero, siempre hemos querido llegar a un acuerdo con ellos, pero ellos no demuestran que son dueños.

\section{¿Ellos qué quieren realmente?}

Ellos quieren que se les pague un derecho. Pero, ¿quién va a querer comprar? ¿quién va a querer invertir de este lado? Nadie. El arancel del terreno de ellos es más caro que acá. Estamos hablando de Surco y San Juan. No ganarían nada. Se les puede pagar un derecho, sí. Pero, que demuestren que son dueños pues.

Yo he sido dirigente. Estuve como 8 años, más o menos desde el 97, así. 


\section{¿Es tranquilo por acá?}

$\mathrm{Si}$, si es tranquilo. Bueno, hay zonas pues. Para el lado de arriba si puede ser peligroso. En todo sitio hay. Acá nos cuidamos entre nosotros. Nadie tiene que agarrar lo que es de otro. Si no, no se puede vivir pe'.

\section{¿Sienten el apoyo del gobierno?}

Mucho prometen y a las finales no hacen nada. Si uno no lo hace, nadie lo va a hacer. Ya es hora que nosotros hagamos algo, de sol en sol. Las cosas están mejorando, ahora casi todo el cerro está iluminado. Hay algunos sitios que reciben más ayuda. Nosotros nos hemos demorado.

\section{¿Cuánta gente vive acá?}

Hay unos 130 lotes. Por familia habrá alrededor de 10 personas. 


\section{Entrevista a Ever}

¿Cuántos años llevas acá?

Unos 4 años. 4 o 5 años más o menos.

¿Antes no había nada?

No, estaba todo vacío. Pero, el muro si estaba.

\section{¿El muro les molesta?}

No, pero es como el muro de Berlín, ¿no? Es ese muro de la vergüenza que separa Casuarinas de San Juan. La vergüenza es de ellos. Creo que es la diferencia de la gente que tiene y la que no. Casuarinas es un sitio ficho.

Desde Benavides se ve esto. El muro no era a esta altura, era un poco más bajo. Luego lo aumentaron y ahora se ve desde la Ricardo Palma. Desde ahí se veía todo esto, y por eso lo levantaron.

¿Crees que por eso lo levantaron?

También creo que para que la gente no pase. Siempre meten a todos en un solo saco, lamentablemente es así. En el lugar donde yo vivo, la gente es tranquila. 


\section{Entrevista a Buenaventura}

Cuéntanos, ¿Cómo fue tu inicio en la comunidad?

Nada había acá. Cuando yo llegué, recién estaban entrando, la gente. Un terreno nomás por familia se permitía. Recién se estaba posicionando la gente. Por acá no había nada.

¿De dónde eres?

De Huánuco.

¿Cuánto tiempo tienes en Lima?

Ya estoy 12 años. En diferentes lugares he vivido. He ido mudando y mudándome.

Ahora ya tienen luz, ¿cierto?

Ahora sí. Gracias al gobierno de PPK. Agua para todos, luz. El gobierno da ese decreto. Se gestiona después de tiempo. Ahora está el agua en gestión. No creo que tome mucho tiempo.

¿Cómo llevas el agua a tu casa?

Ahí viene la cisterna, la bomba. Antes si tenía que cargar, antes no había la carretera y teníamos que cargar. Es caro, 5 soles por envase, un cilindro. 


\section{Entrevista a Fabiola Rosales}

¿Cómo es vivir al costado del muro?

Yo recién tengo un año acá. El muro, más que nada, lo han puesto por la clase social. Porque nosotros somos de clases social más baja, y al otro lado no. Porque al otro lado es La Molina, y a este lado es Pamplona. El muro divide a las dos clases sociales.

Uno va y se para encima del muro y se da cuenta la gran diferencia de las clases sociales en nuestros Perú. Más que nada lo han puesto también para que nosotros no invadamos al otro lado, para que nosotros no sigamos bajando más y más. Es el muro que nos divide.

\section{¿Qué harías si no hubiera muro?}

Es que, si no hubiera muro, las personas, otras personas, o quizás yo también, quisieran invadir más para el otro lado. Aunque por el otro lado no hay salida, todo es privado. Si yo quiero saltar y bajar por ahí para ir por Encalada, no se puede, porque todo es tranqueras y zonas residenciales.

\section{¿Crees que el muro está bien puesto?}

El muro... más que invadir hacia el otro lado, nos divide bastante por las clases sociales. Allá hay un tipo de personas, acá hay otro tipo de personas. Pero ya no podemos hacer nada. 
ANEXO 2: Fotografías finales expuestas 
Abertura

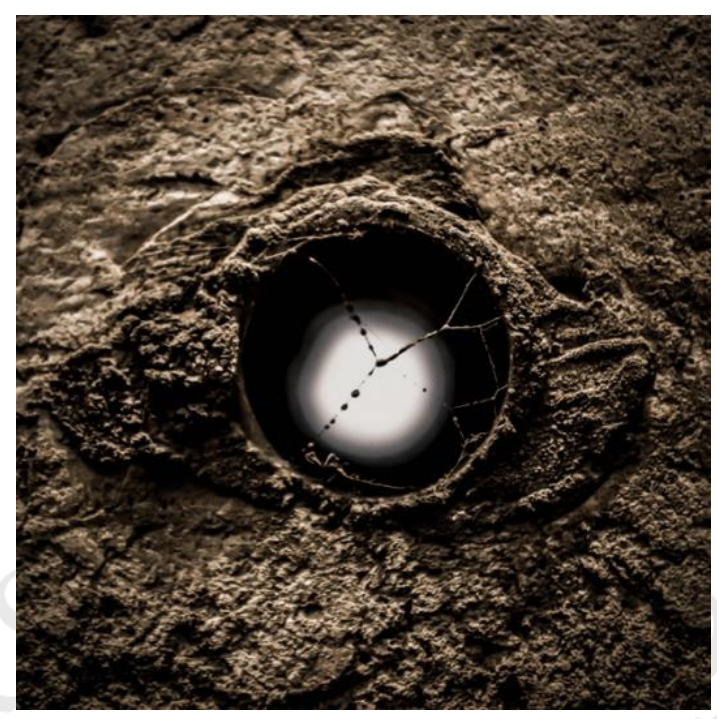

Ajuste

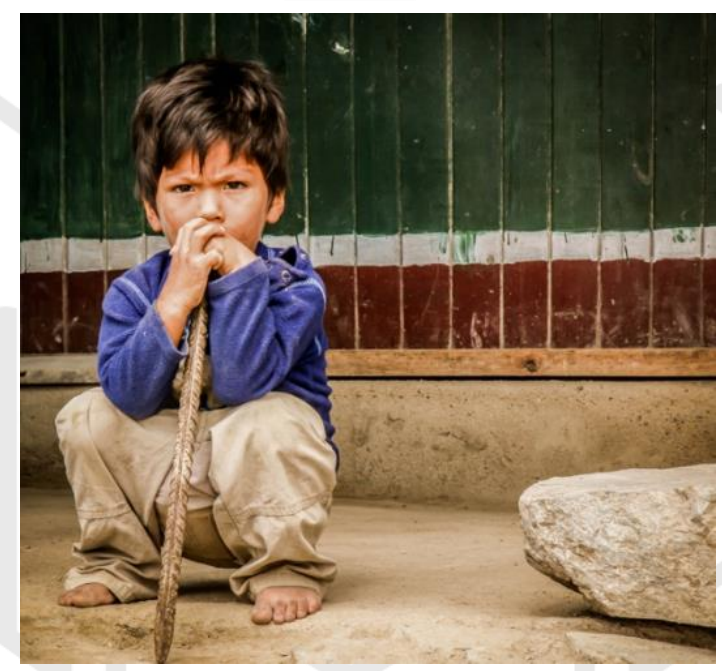

Anexa

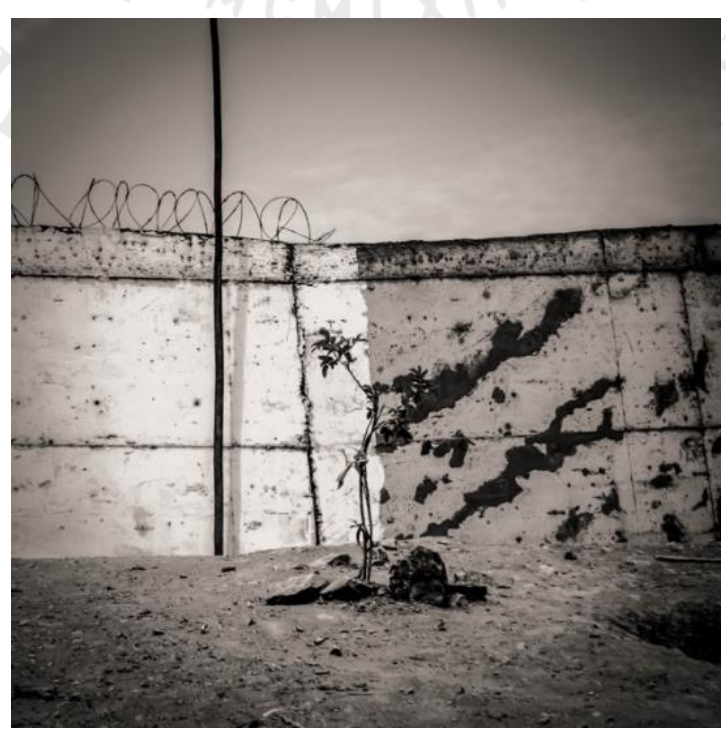


Enredo

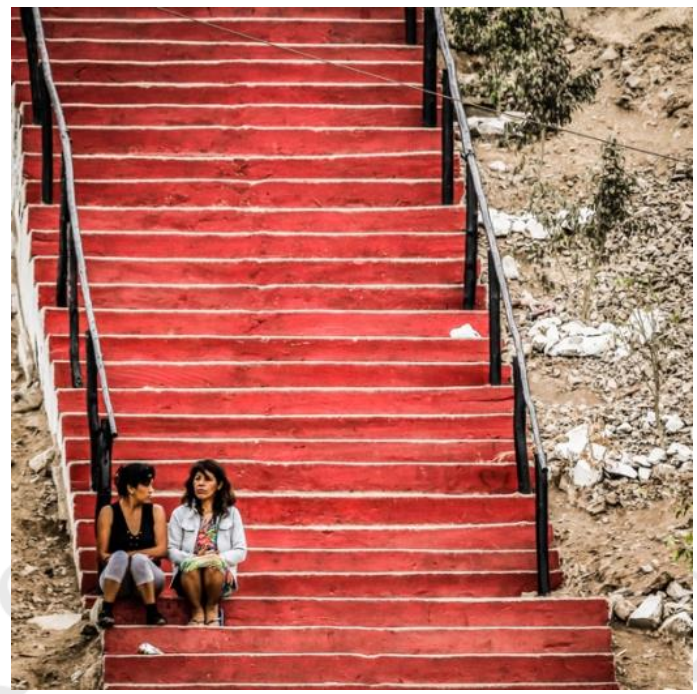

Nota

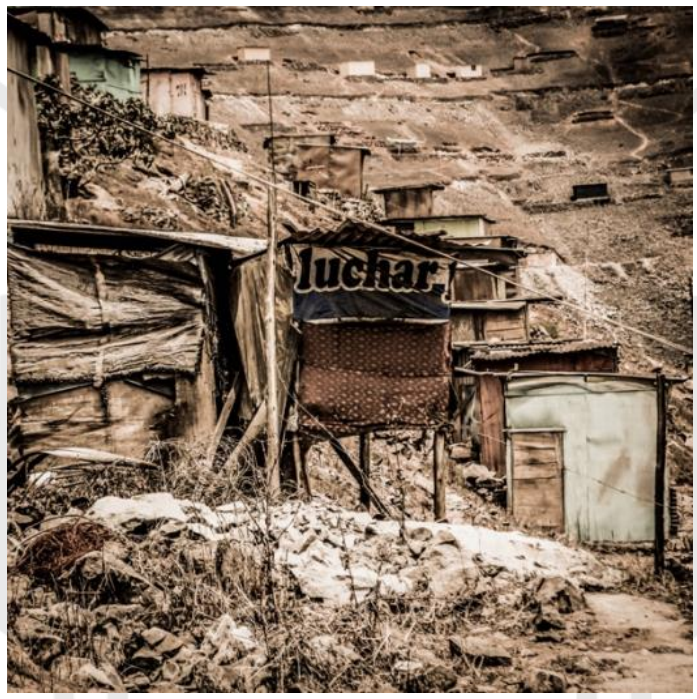

Habitar

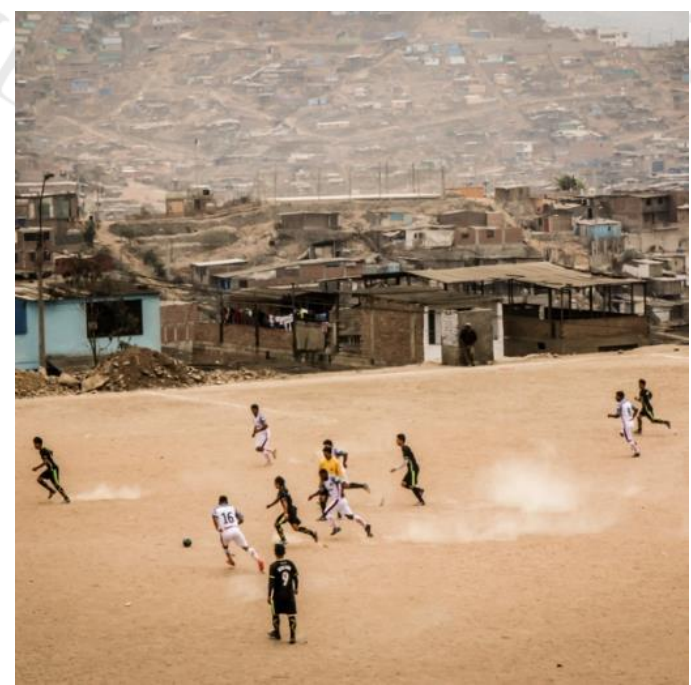


Apertura

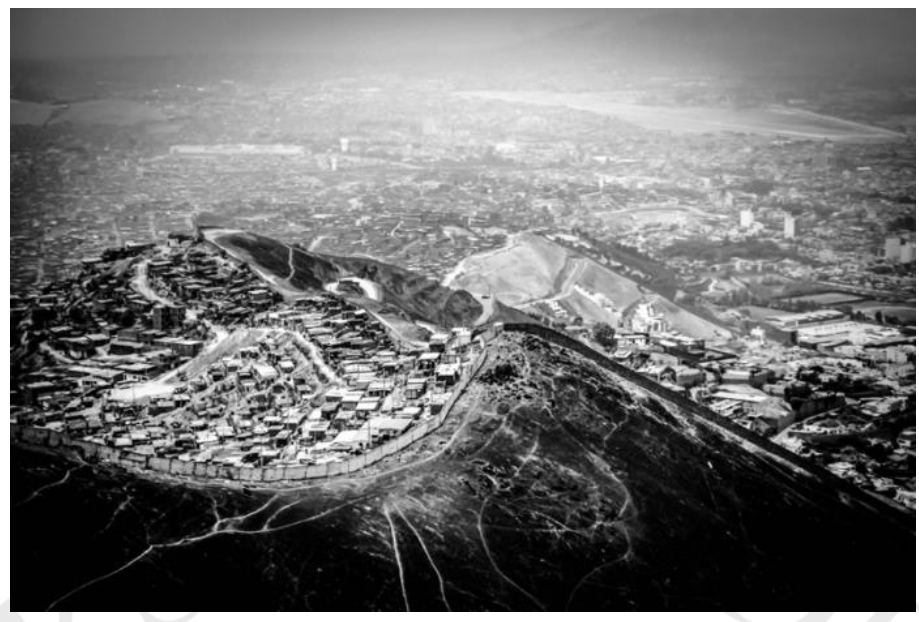

Ascenso

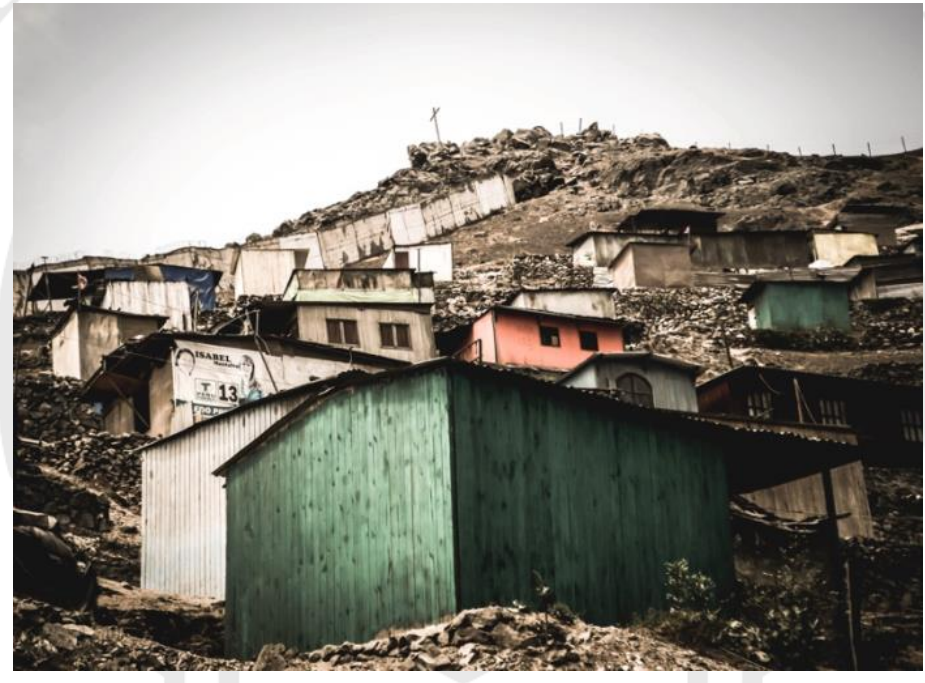

Atadura

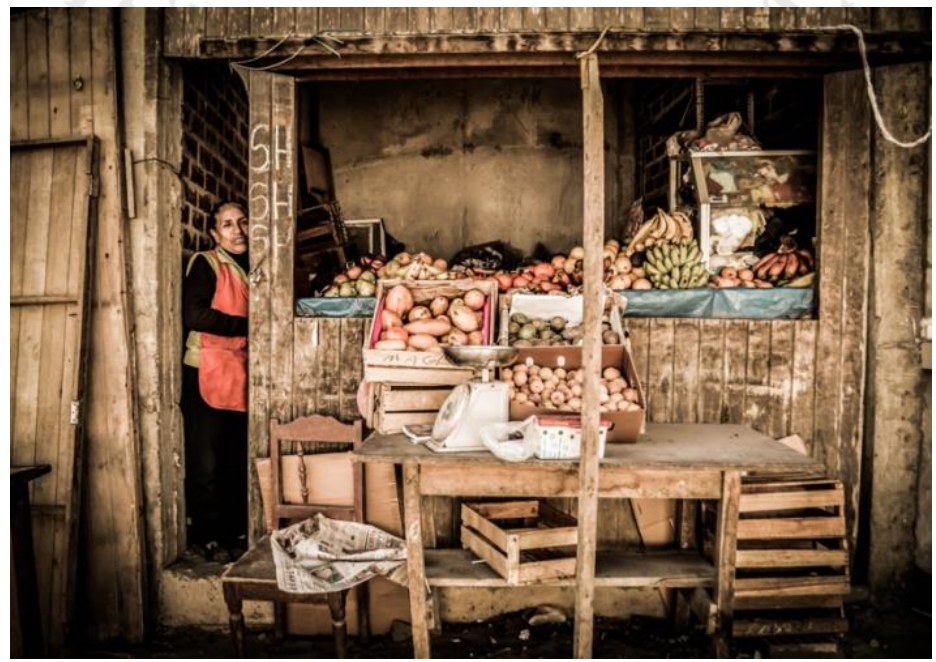




\section{Capas}

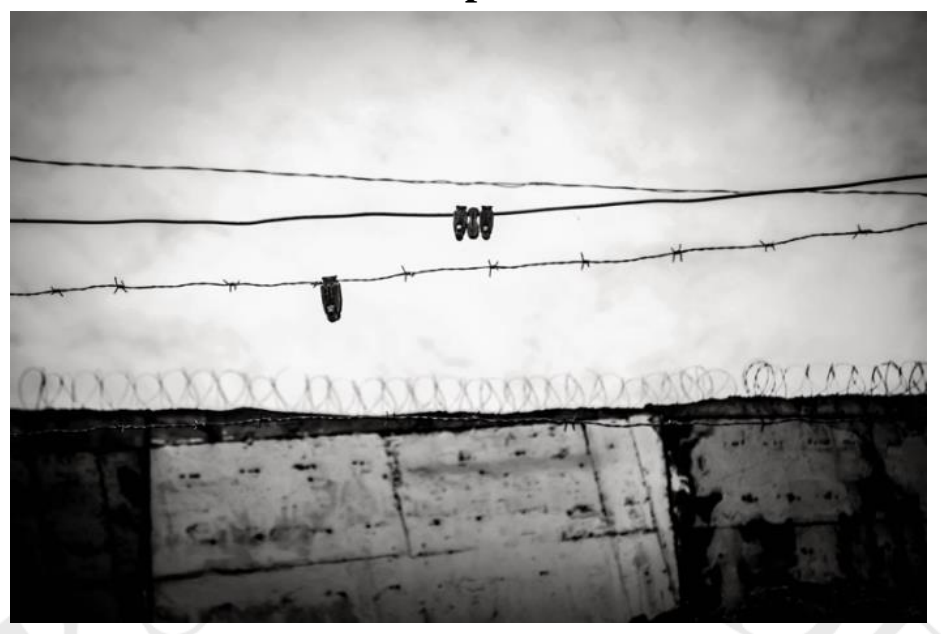

Curvas

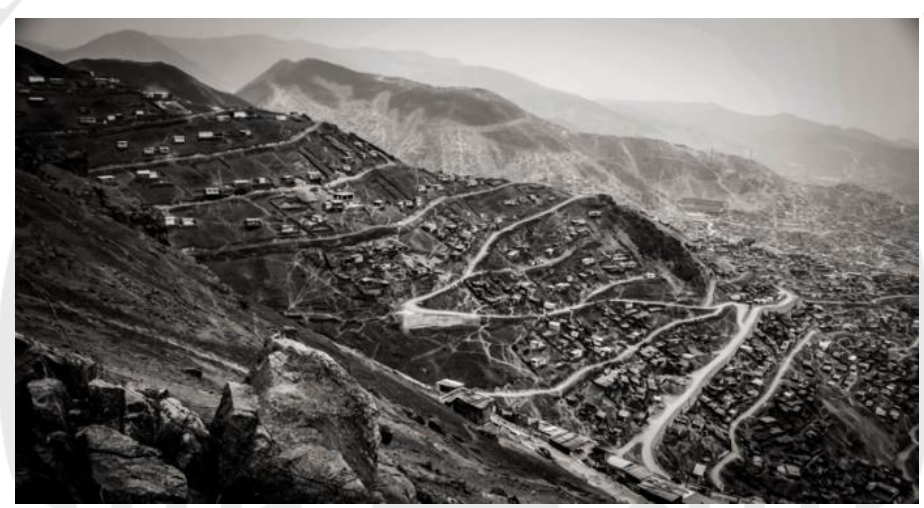

Depender

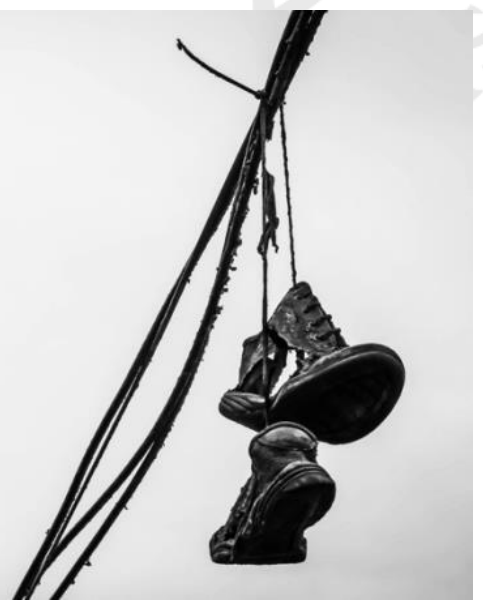




\section{Encuentro}

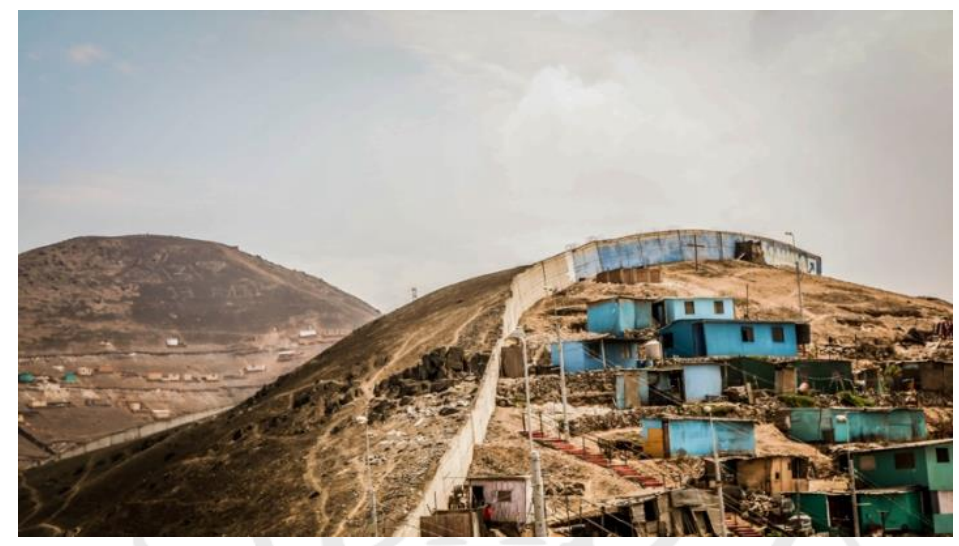

\section{Seguridad}

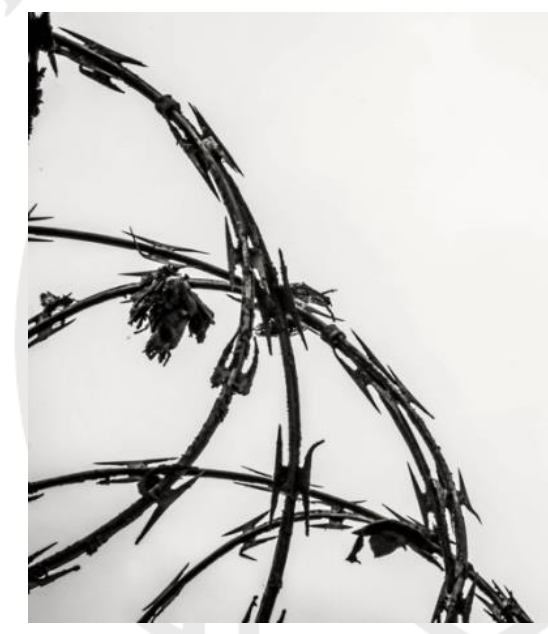

\section{Frontera}

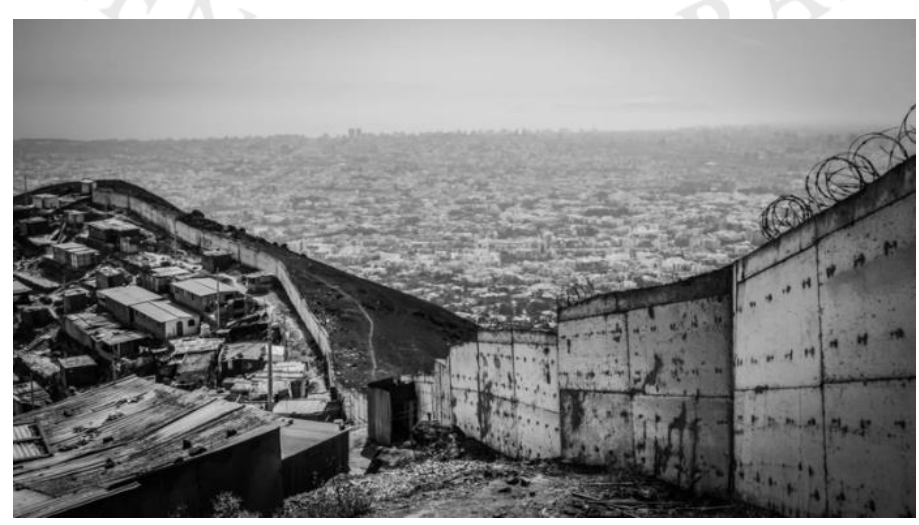




\section{Límite}

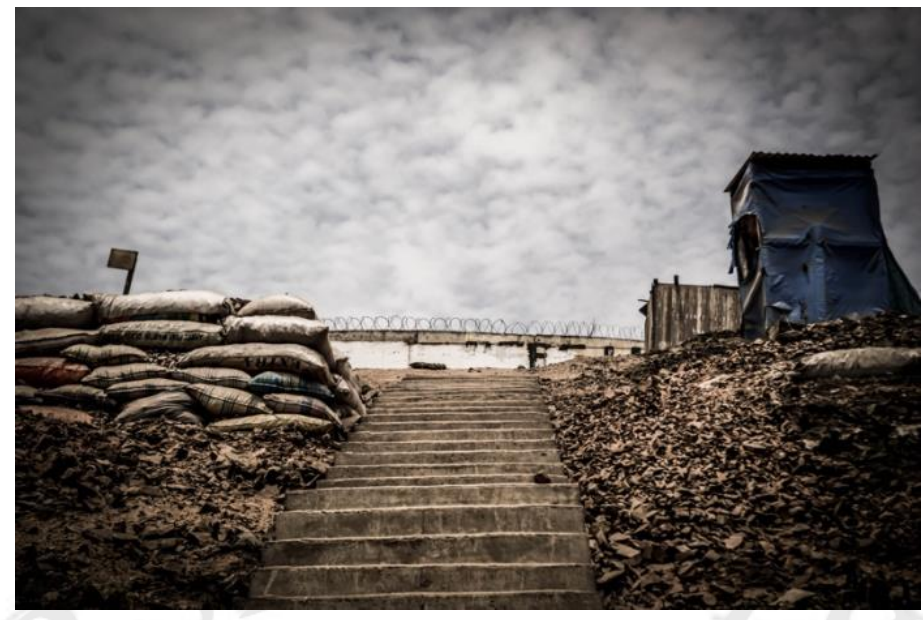

Magda

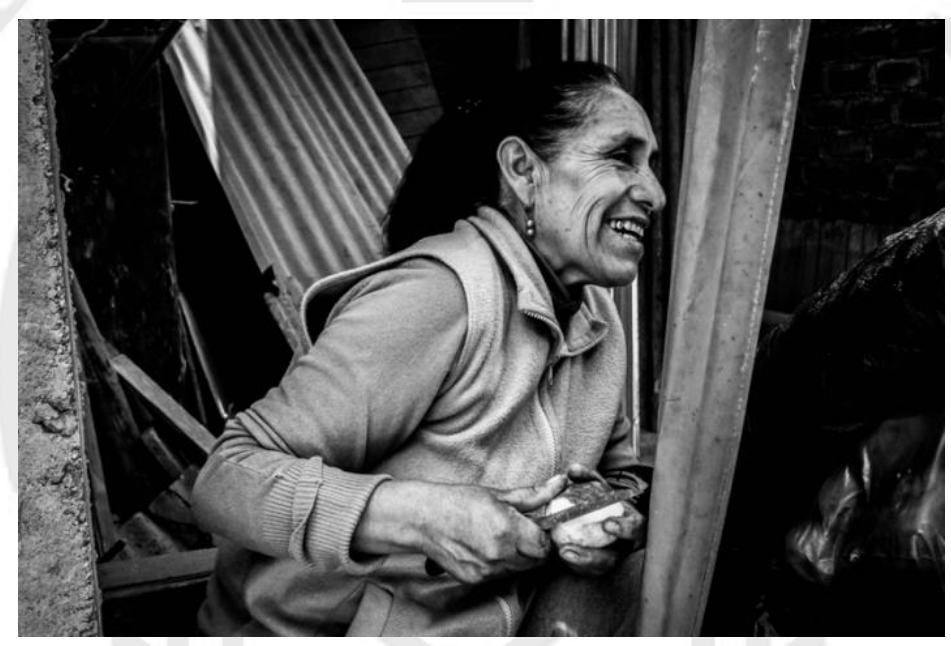

Margen

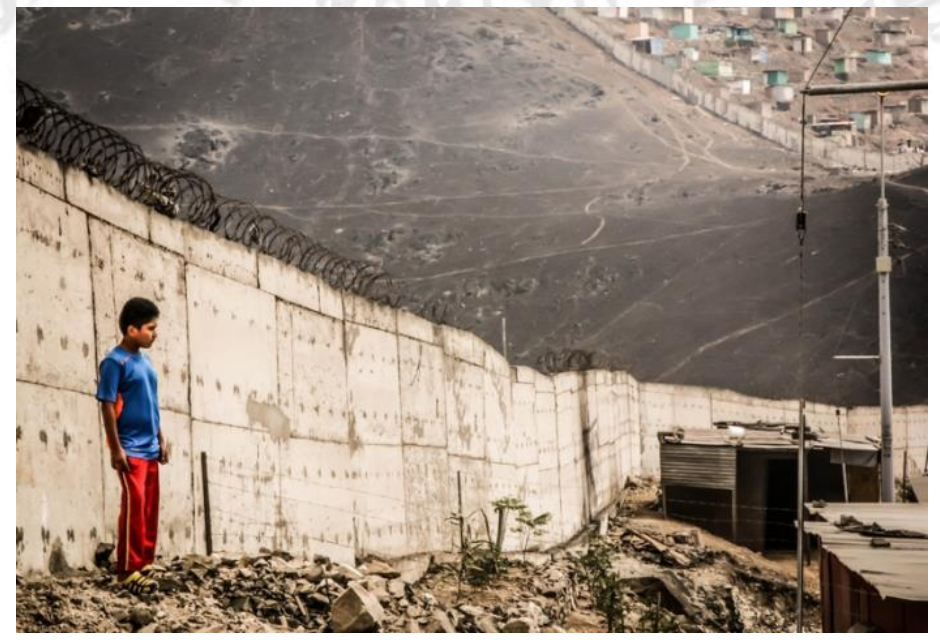




\section{Patria}

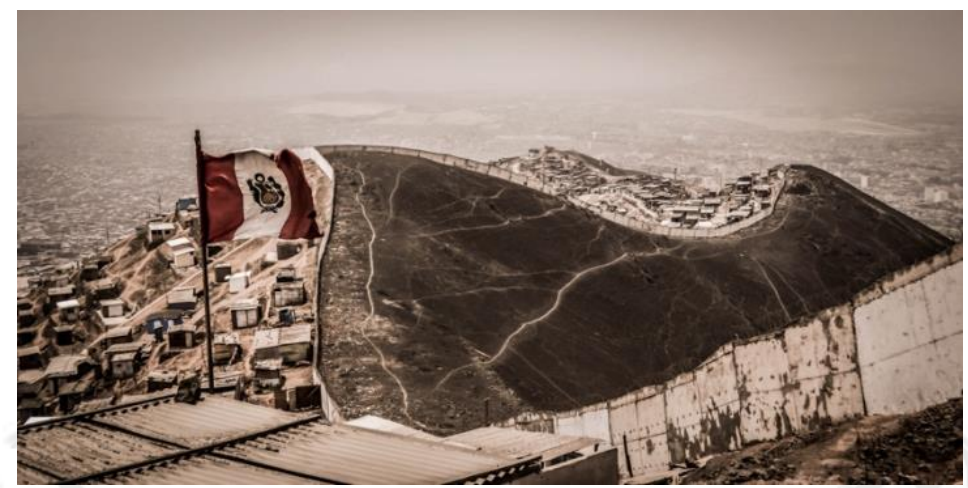

Pausa

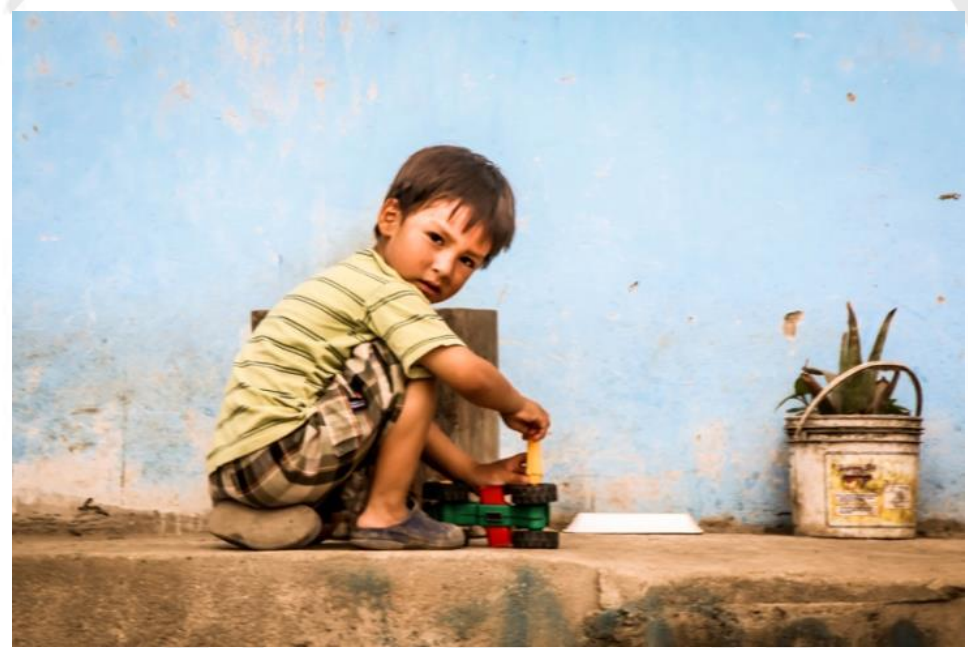

\section{Seguir}

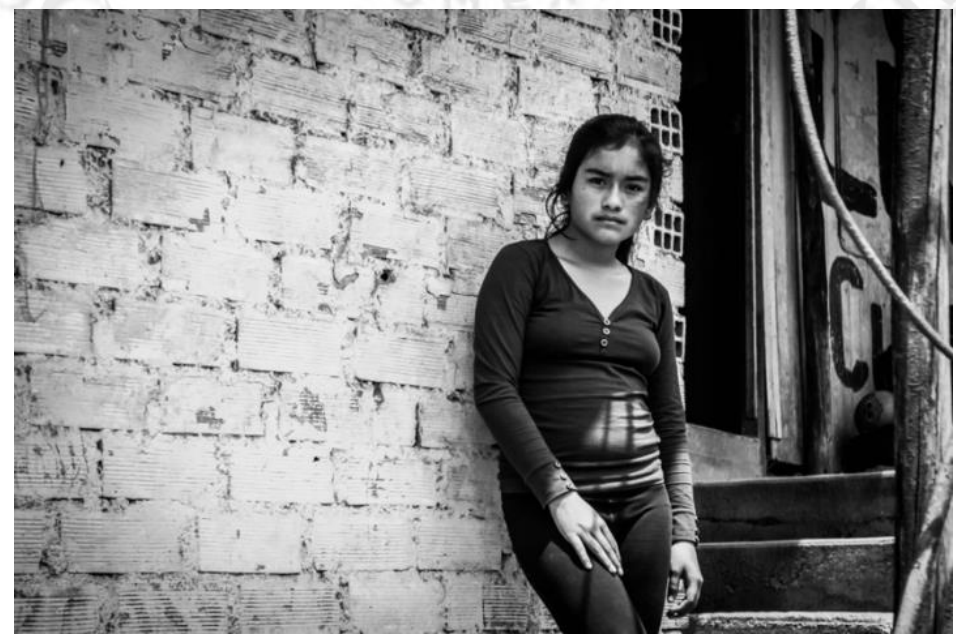


Silencio

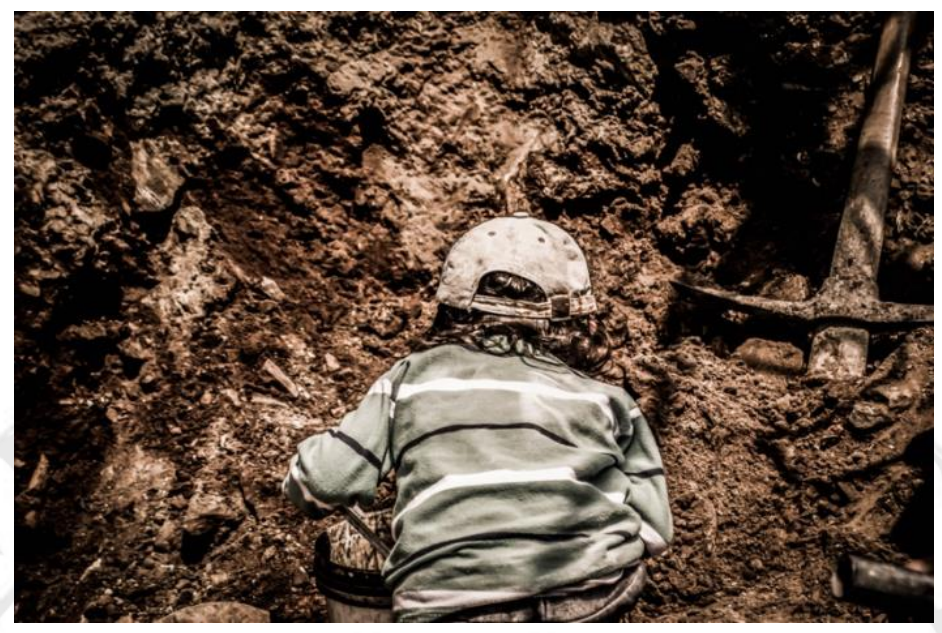

\section{Soltar}

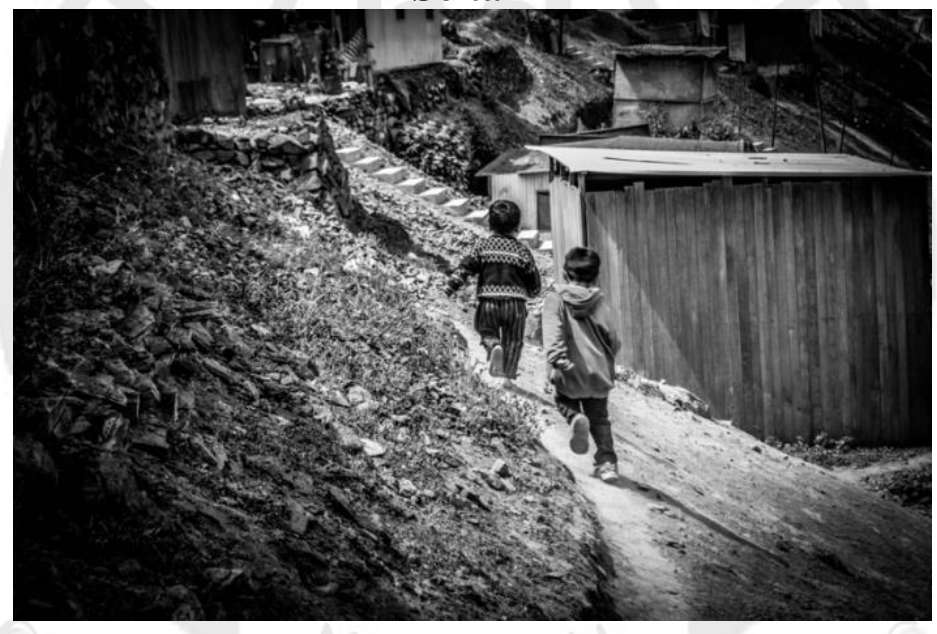

Tragaluz

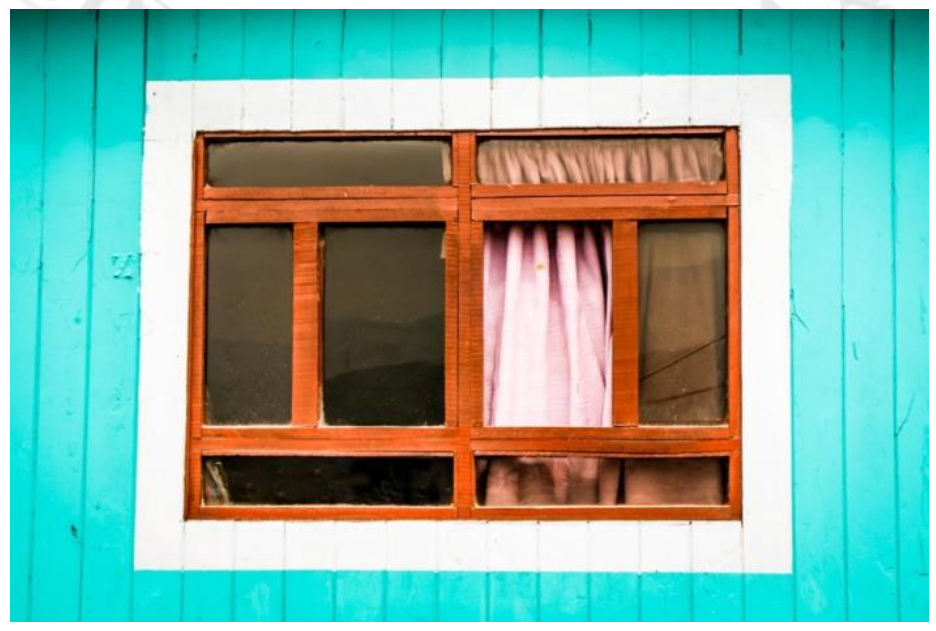

